Article

\title{
New Elastomeric Materials Based on Natural Rubber Obtained by Electron Beam Irradiation for Food and Pharmaceutical Use
}

\author{
Gabriela Craciun ${ }^{1}$, Elena Manaila ${ }^{1, *}$ and Maria Daniela Stelescu ${ }^{2}$ \\ 1 Electron Accelerators Laboratory, National Institute for Laser, Plasma and Radiation Physics, \\ 409 Atomistilor St., 077125 Magurele, Romania; gabriela.craciun@inflpr.ro \\ 2 National R\&D Institute for Textile and Leather-Leather and Footwear Research Institute, \\ 93 Ion Minulescu St., 031215 Bucharest, Romania; dmstelescu@yahoo.com \\ * Correspondence: elena.manaila@inflpr.ro; Tel.: +40-2-1457-4346; Fax: +40-2-1457-4243 \\ Academic Editor: Biqiong Chen \\ Received: 22 September 2016; Accepted: 25 November 2016; Published: 21 December 2016
}

\begin{abstract}
The efficiency of polyfunctional monomers as cross-linking co-agents on the chemical properties of natural rubber vulcanized by electron beam irradiation was studied. The following polyfunctional monomers were used: trimethylolpropane-trimethacrylate, zinc-diacrylate, ethylene glycol dimethacrylate, triallylcyanurate and triallylisocyanurate. The electron beam treatment was done using irradiation doses in the range of $75 \mathrm{kGy}-300 \mathrm{kGy}$. The gel fraction, crosslink density and effects of different aqueous solutions, by absorption tests, have been investigated as a function of polyfunctional monomers type and absorbed dose. The samples gel fraction and crosslink density were determined on the basis of equilibrium solvent-swelling measurements by applying the modified Flory-Rehner equation for tetra functional networks. The absorption tests were done in accordance with the SR ISI 1817:2015 using distilled water, acetic acid (10\%), sodium hydroxide (1\%), ethylic alcohol (96\%), physiological serum (sodium chloride $0.9 \%$ ) and glucose (glucose monohydrate $10 \%$ ). The samples structure and morphology were investigated by Fourier Transform Infrared Spectroscopy and Scanning Electron Microscopy techniques.
\end{abstract}

Keywords: polyfunctional monomers; natural rubber; electron beam irradiation; gel fraction; crosslink density; apsorption tests

\section{Introduction}

Rubber products are widely used in a variety of applications in which they are in contact with food or potable water and their use is growing fast in the pharmaceutical and cosmetic industries (stoppers in syringes, gloves, tubing, hose and in other medical devices). Some elastomers like acrylonitrile butadiene rubber (NBR), butyl rubber (IIR), ethylene propylene diene rubber (EPDM) or natural rubber (NR) are used as finished products or packaging, not only in the mentioned areas [1]. The properties of rubbers, such as cross-link degree or low water and other liquids permeability, good physical and chemical properties and compatibility with food, water, pharmaceutical and cosmetic products as well as the compliance with stringent regulatory requirements, are essential for these fields of applications [1]. The properties and performances of a rubber product depend on many factors including the chemical nature of the rubber, the amount and kinds of ingredients incorporated into the rubber compound, the conditions of processing and vulcanizing, the design of the product and service conditions. The optimization of rubber properties by different methods of vulcanization is required so that one can select the product which will perform satisfactorily in service [2].

There are several possibilities for the cross-linking of natural rubber. The mechanism of vulcanization of NR with sulfur and accelerators has not been clearly elucidated. As universally 
accepted, many reactions occur in series and parallel during NR cured with sulfur. Typically, the chain reactions are initiated by the formation of macro-radicals or macro-ions representing the intermediate cross-link precursor. The vulcanization of NR with sulfur and accelerators leads to the formation of sulfur bridges between $\left(\mathrm{C}-\mathrm{S}_{x}-\mathrm{C}\right)$ macromolecules or cyclic combination of sulfur. Physical and mechanical properties of samples containing $C-S_{x}-C$ cross-linking bridges, exhibit better tensile strength values than those containing $\mathrm{C}-\mathrm{C}$ bonds. Although the vulcanization process by means of sulfur and accelerators leads to obtaining of products with better characteristics, has disadvantages connected with the formation of nitrosamines (many of them having carcinogen potential) during the vulcanization process, and the finished products are toxic, contain heavy metals ( $\mathrm{Zn}$ ), have an unpleasant odor, etc. [3,4].

The vulcanization method using organic peroxides can compete with accelerated sulfur cure, with respect to vulcanization rate. Peroxide vulcanization leads to the formation of a rubber network in which the polymer chains are linked to each other by very stable covalent carbon-carbon bonds. The obtained products have therefore good high temperature properties, such as heat ageing and compression set, compared to sulfur cured articles [5,6]. Other vulcanization systems, i.e., ultraviolet light, electron beam, microwave, resins, etc. have become more attractive with the progressive development of synthetic rubbers $[7,8]$.

Radiation curing has historically been used as an alternative to peroxides in applications where the curatives themselves or side products of vulcanization are viewed as impurities in the final product. Radiation cure has been promoted as a cleaner and more homogeneous cure process. Elastomer crosslinking by means of electron beam (EB) is done without heating and in the absence of vulcanization agents such as sulfur or peroxides. The reaction mechanism is similar to crosslinking with peroxides, but in this case, reaction initiation is due to the action of EB and in the presence of the polyfunctional monomers. Ionizing radiation produces an excitation of polymer molecules. The energies associated with the excitation are dependent on the irradiation dosage of electrons. The interaction results in formation of free radicals formed by dissociation of molecules in the excited state or by interaction of molecular ions. The free radicals or molecular ions can react by connecting the polymer chains directly or initiating grafting reactions. EB vulcanization has demonstrated extremely positive results compared to the conventional curing system, such as no polymer degradation due to high temperature, as EB cross-linking occurs at room temperature; no oxidative degeneration in polymers as observed in classical cross-linking; direct cross-linking by C-C linkage by EB; extremely strong bonds; high degree of cross-linking; extremely short curing cycles; zero blooming effects; extremely high tensile strength; extremely high resistance to compression set; extremely high resistance to oils, grease, and lubricants; highly improved accelerated ageing properties; very high productivity; perfect for thin products; and lower material waste $[9,10]$. Thus, depending on the vulcanization system, different crosslink structures are obtained. In sulfur-cured NR, polysulfide $\left(\mathrm{C}-\mathrm{S}_{x}-\mathrm{C}, x>2\right)$ links are formed, while peroxide or radiation yields only $\mathrm{C}-\mathrm{C}$ crosslinks. Moreover, the free mobility of chain segments of the macromolecules depends on their relative distance, and therefore, on the length of crosslinks. The larger are the crosslinks (larger in the sulfur-cured, $C-S_{x}-C$ structure), the longer the possible displacement during mechanical or thermal strain on the vulcanizate. In sulfur-cured system, the formation of one crosslink may favor another at a vicinal location. At high crosslink densities, this behavior in sulfur-cured NR leads to a uniform distribution of chain lengths between links which may improve crystallization. These crosslink distribution results in a less stressed, stronger network [11]. In addition, the high strength of sulfur-cured NR is due to an internally relaxed network [12]. The low strength of radiation-cured NR compared to that of peroxide and sulfur-cured NR can be related to the loss and isomerization of double bonds due to radiation and also the formation of a less relaxed network. Hence, there are certain differences between vulcanization by either peroxide or radiation ( $\mathrm{C}-\mathrm{C}$ crosslinks) in which the chains are rigidly connected and those with longer mobile crosslinks (polysulfidic crosslinks). The elastic behavior at room temperature improves somewhat with increasing longer crosslinks due to the increased free mobility of the chain segments. 
In contrast, the shorter crosslinks (i.e., C-C crosslinks) restrict the orientation of the macromolecular chains of the NR when stretched. Moreover, the formed bonds cause increased deformation stiffness, because of less mobility of the polymer chains, and consequently lowered mechanical properties.

The technologies based on radiation, as electron beam (EB), have many advantages compared to conventional curing processes. The radiation minimizes deformation of material, increases mechanical strength and thermal stability, and simplifies the curing process [13].

On the other hand, it is an environment-friendly processing technology and the obtained products are free of wastes. The penetration depth of EB is much deeper than in the case of ultraviolet or infrared radiations and for polymerization or other types of curing reactions, the addition of photo-initiators is not required. Direct irradiation of target materials by the means of EB provides a high use efficiency of radiation energy compared with other methods. [14]. Experiments on cross-linking by irradiation with EB have shown that, in many cases, to obtain cross-linking densities equivalent to those obtained by conventional methods, high radiation doses are required. Thus, in order to enhance the efficiency of the EB radiation process, some methods (that include the addition of additives such as sensitizer, plasticizer, polyfunctional monomers or fillers) were experimentally established. These methods lead to the increasing of radical number in the amorphous region and the probability of their recombination. Such compounds (additives) are called radiation cross-linking promoters or prorads [15]. There are two types of radiation cross-linking promoters. One group, indirect cross-linking promoters (halogenated compounds, nitrous oxide, and sulfur monochloride), are not directly involved into the cross-linking reaction but enhance the formation of reactive species (free radicals) that then lead to cross-linking through secondary reactions. The other group, direct cross-linking promoters (maleimides, thiols, and polyfunctional monomers), enters directly into the cross-linking reaction and become the actual connecting molecular links [15]. Co-agents are multi-functional organic molecules which are highly reactive towards free radicals [5]. They are used as reactive additives to boost the vulcanization efficiency [16]. The most used co-agents are molecules with maleimide groups, (meth)acrylate groups, or allylic groups [17]; however, polymeric materials with a high vinyl content, e.g., 1,2-polybutadiene, can also act as co-agents. Polyfunctional monomers (PFMs) are of two types, according to their influence on cure kinetics and ultimate on physical properties of the processed material [5]. PFMs of type I are highly reactive and increase both the rate and the state of cure. PFMs of type II form more stable free radicals. They lead to an increase in crosslink density of the vulcanisate but, unlike of Type I, are not able to increase the cure rate [5,15]. Silica is well known for its adverse effects on health, causing silicosis, cancer (Group 1 according to IARC (the International Agency for Research on Cancer)) tuberculosis, autoimmune and kidney diseases. In 1995, the IARC rated carbon black as IARC classification 2B-possibly carcinogenic to humans and definitely carcinogenic to animals [18-20]. Carbon black is the predominantly used filler and the obtained compounds come directly into contact with food, potable water or products from pharmaceutical and cosmetic industries even if according to the existing food regulations, the type and the amount of carbon black is limited. Other fillers that are still used include clays, calcined clays, silica fillers, talcs, etc. For rubber products that are in contact with water or water-based solutions, silica fillers should be avoided because of their high water absorption [1]. The choice of the vulcanization system depends on the final product applications. For rubber products which enter in contact with food and milk, sulfur and sulfur-donor vulcanization systems are usually used, while for pharmaceutical applications and potable water both peroxide and sulfur-based vulcanization systems are used. It has to be underlined that because of the vulcanization process complexity, the accelerators may remain in un-reacted form or may form byproducts, some of which can migrate into food and water and may be dangerous for human health [1].

The objective of this research is to obtain a new elastomeric material based on natural rubber (NR) and polyfunctional monomers by electron beam cross-linking. 


\section{Experimental}

\subsection{Materials}

The following raw materials were used: NR Crep 1X (Mooney viscosity of $74 \mathrm{ML}_{1+4}$ at $100{ }^{\circ} \mathrm{C}$, volatile materials content of $0.32 \%$, nitrogen content of $0.38 \%$, ash content of $0.22 \%$, impurities content of 0.021\%), antioxidant Irganox 1010 and polyfunctional monomers (PFMs) (triallylcyanurate Luvomaxx TAC DL70, triallylisocyanurate Luvomaxx TAIC DL70C, trimethylolpropane trimethacrylate Luvomaxx TMPT DL75, ethylene glycol dimethacrylate Luvomaxx EDMA DL75, zincdiacrylate Luvomaxx ZDA GR75). Table 1 presents the chemical structures, types, functionalities and characteristics of polyfunctional monomers that have been used.

Table 1. Comparison between chemical structures and characteristics of polyfunctional monomers that have been used.

\begin{tabular}{|c|c|c|c|}
\hline $\begin{array}{l}\text { Polyfunctional } \\
\text { Monomer }\end{array}$ & Type/Functionality & Chemical Characteristics & Chemical Structure \\
\hline $\begin{array}{l}\text { Trimethylolpropane- } \\
\text { trimethacrylate } \\
\text { (TMPT) }\end{array}$ & $\mathrm{I} / 3$ & $\begin{array}{l}\text { - } \quad \text { molecular weight: } 338.4 \mathrm{~g} / \mathrm{mol} \text {; } \\
\text { - } \quad \text { deiling point: }>200{ }^{\circ} \mathrm{C} \text {; } 1.06 \mathrm{~g} / \mathrm{cm}^{3} ; \\
\text { - } \\
75 \% \pm 3 \% \text { active ingredient }\end{array}$ & \\
\hline $\begin{array}{l}\text { Zinc-diacrylate } \\
\text { (ZDA) }\end{array}$ & $\mathrm{I} / 2$ & $\begin{array}{l}\text { - } \text { molecular weight: } 207.5 \mathrm{~g} / \mathrm{mol} \text {; } \\
\text { - } \quad \text { boiling point: } 141{ }^{\circ} \mathrm{C} ; \\
\text { - } \\
\text { - } \\
\text { - }\end{array}$ & $\mathrm{O}$ \\
\hline $\begin{array}{l}\text { Ethylene glycol } \\
\text { dimethacrylate } \\
\text { (EDMA) }\end{array}$ & $\mathrm{I} / 2$ & $\begin{array}{l}\text { - } \quad \text { molecular weight: } 198.2 \mathrm{~g} / \mathrm{mol} \text {; } \\
\text { - } \quad \text { deiling point: } 85^{\circ} \mathrm{C} \text {; } \\
\text { - } \quad 75 \% \pm 3 \% \text { active ingredient }\end{array}$ & \\
\hline $\begin{array}{l}\text { Triallylcyanurate } \\
\text { (TAC) }\end{array}$ & II $/ 3$ & $\begin{array}{l}\text { - } \quad \text { molecular weight: } 249.2 \mathrm{~g} / \mathrm{mol} \text {; } \\
\text { - } \quad \text { boiling point: } 119-120^{\circ} \mathrm{C} ; \\
\text { - } \quad 30 \% \text { active synthetic silica }\end{array}$ & \\
\hline $\begin{array}{l}\text { Triallylisocyanurate } \\
\text { (TAIC) }\end{array}$ & II $/ 3$ & $\begin{array}{l}\text { - } \quad \text { molecular weight: } 249.2 \mathrm{~g} / \mathrm{mol} \text {; } \\
\text { - } \quad \text { boiling point: } 149-152{ }^{\circ} \mathrm{C} \text {; } \\
\text { - } \quad \text { density } 1.16 \mathrm{~g} / \mathrm{cm}^{3} \\
\text { - } 30 \% \text { active synthetic silica }\end{array}$ & . \\
\hline
\end{tabular}

\subsection{Blends Preparation}

Samples were prepared on an electrically heated laboratory roller. For preparation of NR with PFMs, the blend constituents were added in the following sequences and amounts: 100 phr NR and 3 phr PFMs (TAC, TAIC, TMPT, EDMA and ZDA, respectively). The process variables were as follows: temperature $25^{\circ} \mathrm{C}-50{ }^{\circ} \mathrm{C} \pm 5{ }^{\circ} \mathrm{C}$, friction ratio 1.1 and total blending time $5 \mathrm{~min}$. Plates required for physical and chemical tests with sizes of $150 \times 150 \times 2 \mathrm{~mm}^{3}$ were obtained by pressing in a hydraulic press at $110{ }^{\circ} \mathrm{C} \pm 5^{\circ} \mathrm{C}$ and $150 \mathrm{MPa}$. These samples were named: NR/TAC, NR/TAIC, NR/TMPT, NR/EDMA and NR/ZDA. 


\subsection{Electron Beam Irradiation}

The samples prepared as was described above, were irradiated using the electron beam accelerator called ALID-7 in the dose range of 75 kGy-300 kGy. ALID-7 was built in the Electron Accelerator Laboratory from the National Institute for Lasers, Plasma and Radiation Physics, Bucharest, Romania. It is a travelling-wavetype accelerator, operating at a wavelength of $10 \mathrm{~cm}$. The accelerating structure is a disk-loaded tube operating in the $\pi / 2$ mode. The optimum values of the electron beam, peak current IEB and EB energy EEB to produce maximum output power PEB for a fixed pulse duration $\tau E B$ and repetition frequency $\mathrm{fEB}$ are as follows: $\mathrm{EEB}=5.5 \mathrm{MeV}, \mathrm{IEB}=130 \mathrm{~mA}, \mathrm{PEB}=670 \mathrm{~W}(\mathrm{fEB}=250 \mathrm{~Hz}$, $\tau \mathrm{EB}=3.75 \mu \mathrm{s})$. The EB effects are related to the absorbed dose (D) expressed in Gray or $\mathrm{J} \cdot \mathrm{kg}^{-1}$ and absorbed dose rate $\left(D^{*}\right)$ expressed in $\mathrm{Gys}^{-1} \mathrm{or} \mathrm{J} \cdot \mathrm{kg}^{-1} \cdot \mathrm{s}^{-1}$. Layers of three sandwiched sheets covered in polyethylene foils were irradiated at 75, 150, 225 and $300 \mathrm{kGy}$, in atmospheric conditions and at room temperature of $25^{\circ} \mathrm{C}$.

Radiation dosimetry was assured by using the PTW-UNIDOS high performance secondary standard dosimeter (PTW, Freiburg, Germany) for universal use, connected to the Advanced Markus Electron Chamber (PTW Freiburg, Germany) that is a plane parallel ion chamber for high-energy electron measurements. The chamber features a flat energy response within the nominal energy range from 2 to $45 \mathrm{MeV}$. It was placed under the accelerator exit window, in the middle of the electron beam cross section and the values obtained were read in the accelerator control room with the PTW-UNIDOS dosimeter, $10 \mathrm{~s}$ for each measurement and after that an average dose rate was considered.

A very important step in irradiation activities is the correct establishing of the penetration depth, in order to ensure equal doses at the entry and at the exit of the irradiated sample. The thickness requirement of the product can be calculated from the following relation:

$$
E=2.6 \cdot t \cdot \rho+0.3
$$

where $E(\mathrm{MeV})$ is the useful beam energy, in our case $5.5 \mathrm{MeV}, t(\mathrm{~cm})$ is the thickness of the product and $\rho\left(\mathrm{g} \cdot \mathrm{cm}^{-3}\right)$ is the sample density, which was measured as being $1 \mathrm{~g} \cdot \mathrm{cm}^{-3}[21,22]$. Thus, the thickness of the irradiated samples is $20 \mathrm{~mm}$.

\subsection{Sol-Gel Analysis}

Sol-gel analysis wAs performed on cross-linked NR rubber (with and without PFMs) in order to determine the mass fraction of insoluble NR (the network material resulting from the network-forming cross-linking process) gel fraction. The samples were weighed and swollen in toluene for $72 \mathrm{~h}$ in order to remove any scissioned fragments and unreacted materials. Then they were dried in air for 6 days and in a laboratory oven at $80{ }^{\circ} \mathrm{C}$ for $12 \mathrm{~h}$ to completely remove the solvent and finally, reweighed. The gel fraction was calculated as follows:

$$
\text { Gelfraction }=\frac{m_{s}}{m_{i}} \times 100
$$

where $m_{s}$ and $m_{i}$ are the weight of the dried sample after swollen and the weight of the sample before swollen, respectively [23-25].

\subsection{Crosslink Density}

The crosslink density of the samples $(v)$ was determined on the basis of equilibrium solvent-swelling measurements (in toluene at $23{ }^{\circ} \mathrm{C}-25^{\circ} \mathrm{C}$ ) by application of the well-known modified Flory-Rehner equation for tetra functional networks. The samples having the thickness of $2 \mathrm{~mm}$ were initially weighed $\left(m_{i}\right)$ and immersed in toluene for $72 \mathrm{~h}$. Then, the swollen samples were removed and cautiously blotted with tissue paper to remove the excess solvent before being weighed $\left(m_{g}\right)$ in special ampoules to avoid toluene evaporation during weighing. All samples were dried in air for 6 days and in a laboratory oven at $80{ }^{\circ} \mathrm{C}$ for $12 \mathrm{~h}$ to completely remove the solvent. Finally, the samples 
were weighed for the last time $\left(m_{s}\right)$ and the volume fractions of polymer in the samples at equilibrium swelling $v_{2 \mathrm{~m}}$ were determined from swelling ratio $G$ as follows:

$$
v_{2 \mathrm{~m}}=\frac{1}{1+G}
$$

where

$$
G=\frac{m_{g}-m_{s}}{m_{s}} \times \frac{\rho_{r}}{\rho_{s}}
$$

and $\rho_{r}$ and $\rho_{s}$ are the densities of rubber samples and solvent $\left(0.866 \mathrm{~g} / \mathrm{cm}^{3}\right.$ for toluene), respectively.

The densities of elastomer samples were determinate by the hydrostatic weighing method, according to the SR ISO 2781/2010. Through this method, the volume of a solid sample is determined by comparing the weight of the sample in air to the weight of the sample immersed in a liquid of a known density. The volume of the sample is equal to the difference between the two weights divided by the density of the liquid. The cross-link densities of the samples, $v$, were determined from measurements in a solvent, using the Flory-Rehner relationship:

$$
v=-\frac{\operatorname{Ln}\left(1-v_{2 \mathrm{~m}}\right)+v_{2 \mathrm{~m}}+\chi_{12} v_{2 \mathrm{~m}}^{2}}{V_{1}\left(v_{2 \mathrm{~m}}^{1 / 3}-\frac{v_{2 m}}{2}\right)}
$$

where $V_{1}$ is the molar volume of solvent $\left(106.5 \mathrm{~cm}^{3} / \mathrm{mol}\right.$ for toluene), $v_{2 \mathrm{~m}}$ is the volume fraction of polymer in the sample at equilibrium swelling, and $\chi_{12}$ is the Flory-Huggins polymer-solvent interaction term (the value of $\chi_{12}$ is 0.393 for toluene) $[23,24]$.

\subsection{Fourier Transform Infrared Spectroscopy (FTIR)}

Changes of the chemical structure of NR/PFMs samples were highlighted using a FTIR spectrophotometer (TENSOR 27, Bruker, Ettlingen, Germany) by ATR measurement method. Samples spectra are the average of 30 scans realized in absorption in the range of $4000 \mathrm{~cm}^{-1}-600 \mathrm{~cm}^{-1}$, with a resolution of $4 \mathrm{~cm}^{-1}$.

\subsection{Scanning Electron Microscopy (SEM)}

The surface texture of the NR/PFMs samples was examined using a scanning electron microscope. (FEI/Phillips, Hillsboro, OR, USA). All the surfaces were fractured under liquid nitrogen, sputtered with gold palladium and then scanned at an accelerating voltage up to $30 \mathrm{kV}$.

\subsection{Aqueous Solutions Absorption Test}

The effects of aqueous solution absorption on NR/PFMs samples were investigated in accordance with SR ISO 1817:2015, using the method described forward. The samples were dried in a laboratory oven at $80^{\circ} \mathrm{C}$ for $2 \mathrm{~h}$ and then have been chilled at room temperature in desiccators before weighing. Three pieces of approximately uniform sizes and weights $(\sim 0.5 \mathrm{~g})$ were accurately weighed $\left(m_{i}\right)$ and immersed in $50 \mathrm{~mL}$ of aqueous solution at room temperature $\left(23 \pm 2{ }^{\circ} \mathrm{C}\right)$ for $22 \pm 0.25 \mathrm{~h}$. Samples were removed from the bottles after $22 \mathrm{~h}$ and the wet surfaces were quickly wiped using a clean dry cloth or tissue paper. The weights $\left(m_{f}\right)$ of the specimens after swelling were determined. The aqueous solution absorption was calculated as follows:

$$
\text { Water uptake }(\%)=\frac{m_{f}-m_{i}}{m_{i}} \times 100
$$

Table 2 presents the types of aqueous solutions used in the experiments and the range of absorption according to SR ISO 1817:2015. The chosen aqueous solutions are widely used in two industries that use natural rubber hoses: "food" and "pharmaceutical". 
Table 2. The aqueous solutions used for testing the resistance of NR/PFMs samples.

\begin{tabular}{|c|c|c|c|}
\hline Aqueous Solutions & Chemical Formula & Molar Mass $\left(\mathrm{g} \cdot \mathrm{mol}^{-1}\right)$ & Range of Absorption \\
\hline distilled water & $\mathrm{H}_{2} \mathrm{O}$ & 18.01 & \\
\hline $\begin{array}{l}\text { sodium hydroxide } \\
(\mathrm{NaOH}, 1 \%)\end{array}$ & $\mathrm{NaOH}$ & 39.99 & $-2 \%-+4 \%$ \\
\hline ethylic alcohol (96\%) & ${\stackrel{\mathrm{OH}}{\mathrm{CH}_{3}-\mathrm{CH}_{2}}}^{\mathrm{CH}_{2}}$ & 46.07 & $-2 \%-+7 \%$ \\
\hline $\begin{array}{l}\text { physiological serum } \\
(\mathrm{NaCl}, 0.9 \%)\end{array}$ & $\mathrm{NaCl}$ & 58.44 & $-2 \%-+4 \%$ \\
\hline acetic acid $(10 \%)$ & $\mathrm{CH}_{3}-\mathrm{C}$ & 60.05 & $-2 \%-+6 \%$ \\
\hline $\begin{array}{c}\text { glucose } \\
\text { (glucose monohydrate, } 10 \% \text { ) }\end{array}$ & $\underbrace{\mathrm{OH}}_{\mathrm{OH}} \underbrace{\mathrm{CH}}_{\mathrm{OH}}$ & 180.16 & $-2 \%-+4 \%$ \\
\hline
\end{tabular}

\section{Results and Discussion}

\subsection{Gel Fraction and Cross-Link Density of the Blends}

Radiation effects on polymers/rubbers have been investigated over the last few decades. Among other effects, high-energy radiation produces cross-linking and degradation (chain scissions) reactions in polymeric materials. The cross-linking process causes formation of an insoluble gel if it predominates over degradation. Generally, the radiation-induced cross-linking yield can be estimated from the gel fraction determination [26]. If the gel content value increases, the cross-linking also increases [27]. The variations of gel content with the irradiation dose for NR and for NR/PFMs are shown in Figure 1.

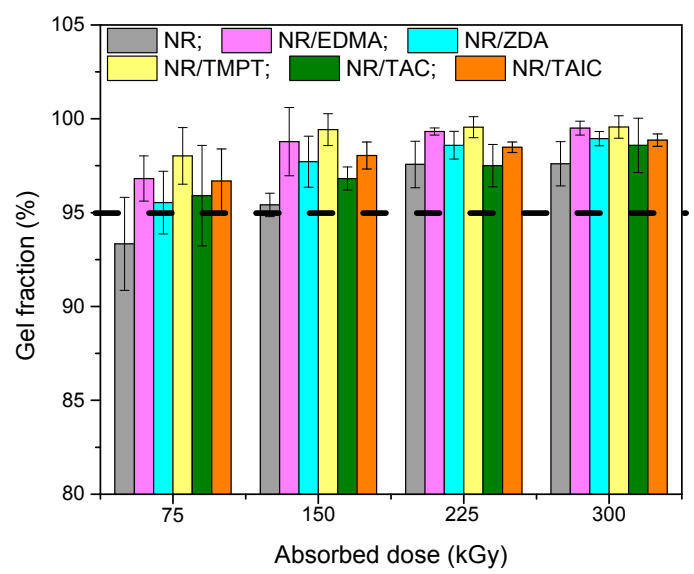

Figure 1. Effects of the absorbed dose and PFMs on gel content.

Even if the gel fraction values are comparable, for samples with and without PFMs, the appearance of the plateau (gel fraction value over 95\%) at a lower radiation dose (150 kGy) than for samples without PFMs may indicate an increasing of NR sensibility to radiation dose. The cross-linking process was evaluated by the cross-link density determinations (number of cross-links per unit volume in a polymer network). It is well known that, for the cross-linking of NR and as a consequence for the obtaining of high cross-link densities, high radiation doses are required. However, in the same 
time the process and the material properties are threatened by the radiation-induced degradation appearance [28]. One of the reasons that the PFMs were used in our experiments was to reduce the required radiation dose. Because of their high reactivity, at the interaction with NR, the PFMs produce a network structure even at smaller doses and in this way the cross-link density is improved. The effects of five different types of PFMs (TAC and TAIC of Type II, and TMPT, EDMA and ZDA of Type I) used as cross-linking co-agents for $\mathrm{EB}$ vulcanization of NR, on the cross-link density improvement are presented in Figure 2.

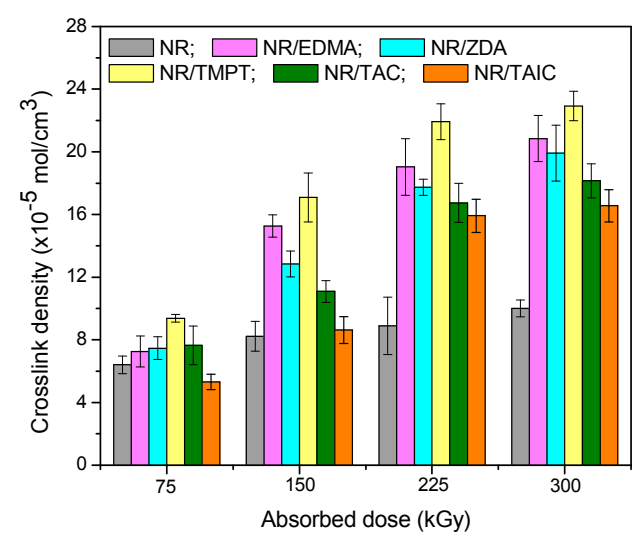

Figure 2. Effects of absorbed dose and PFMs type on cross-link density.

The reactivity, functionality and solubility of the PFMs in the NR have contributed to the increasing of the cross-link densities. The presence of the PFMs have favored the network formation by the increasing of the local concentration of highly reactive groups. The incorporation of PFMs into the network can also have a favorable impact on the physical properties of the vulcanizate. The results obtained by other researchers have been offered a better understanding of PFMs activity and also, based on their structure, of the influence on the composition and microstructure of the cured elastomers. Explorations regarding the PFMs and elastomer structure-property co-relationship have constituted the background in the PFMs selection for our study [29]. PFMs are classified based on their contributions to cure and thus divided into two basic types. Type I co-agents increase both the rate and state of cure. They are typically polar, multifunctional low molecular weight compounds that form very reactive radicals through addition reactions. These "monomers" can be homo-polymerized or grafted to polymer chains. Type II co-agents form less reactive radicals and contribute only to the state of cure. They form radicals primarily through hydrogen abstraction [5,30,31].

The influence of PFMs on cross-link density (Figure 2) for the samples vulcanized through EB irradiation is as follows: TMPT $>$ EDMA $>$ ZDA $>$ TAC $>$ TAIC. The addition of TMPT (Type I, functionality 3) significantly increases cross-link density compared with the control samples (NR) and other PFMs. By using TMPT, not only has the rate of cure been increased, but also the cross-link density or state of cure [31]. In an irradiation cure system, the gel content and cross-link density of samples increase with the absorbed dose increasing due to the formation of a three-dimensional network structure [32]. The mechanism of cross-link formation using PFMs (co-agents) appears to be at least partially dependent on their class. In Figure 2, how the cross-link density has been changed by the addition of Type I (TMPT, EDMA and ZDA) or Type II (TAC and TAIC) co-agents can be seen. Because of their high reactivity, the co-agents of Type I, have favored the addition reactions that lead to the homo-polymerization and subsequent grafting to polymer chains, through either direct addition reactions (unsaturated polymers) or through abstraction/coupling reactions with saturated or unsaturated polymer chains. Regardless of mechanism, the Type I co-agents have increased cross-link density. The addition of a Type II co-agent had a less impact on cross-link density. The cross-linking of elastomer by means of EB irradiation was done without additional heating and reaction initiation has been realized by the action of EB and the presence of the PFMs. 
The EB radiation produces an excitation of polymer molecules. The energies associated with the excitation depend on the absorbed dose of electrons. The interaction results in formation of free radicals by dissociation of molecules in the excited state, as is presented in Figure 3. These free radicals can react by connecting the polymer chains directly or initiating grafting reactions.

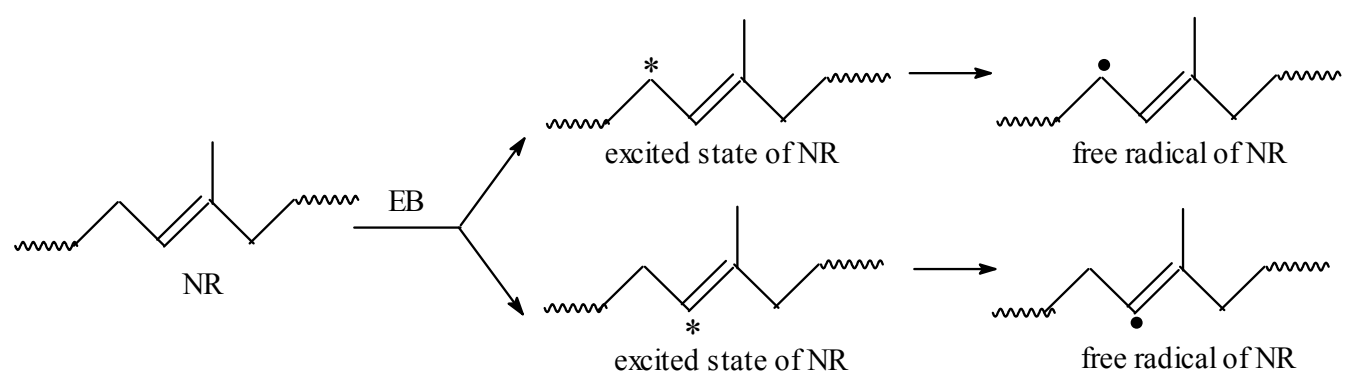

Figure 3. Scheme of the obtaining of NR macro-radicals by EB irradiation.

As it was mentioned in the previous paragraph, Type I and II co-agents differ in their reactivity during vulcanization process. Accordingly, the reaction mechanisms that they follow also differ. Two possible mechanisms of NR cross-linking/grafting in the presence of TMPT and TMPT cyclo-polymerization on NR, respectively, are presented in Figures 4 and 5.

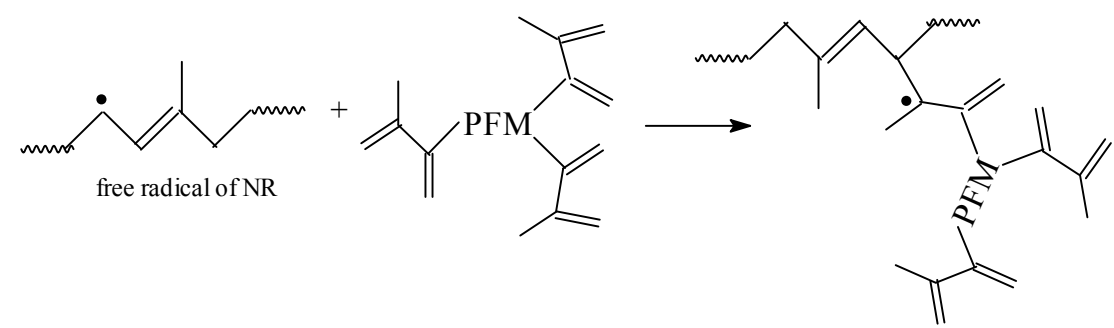

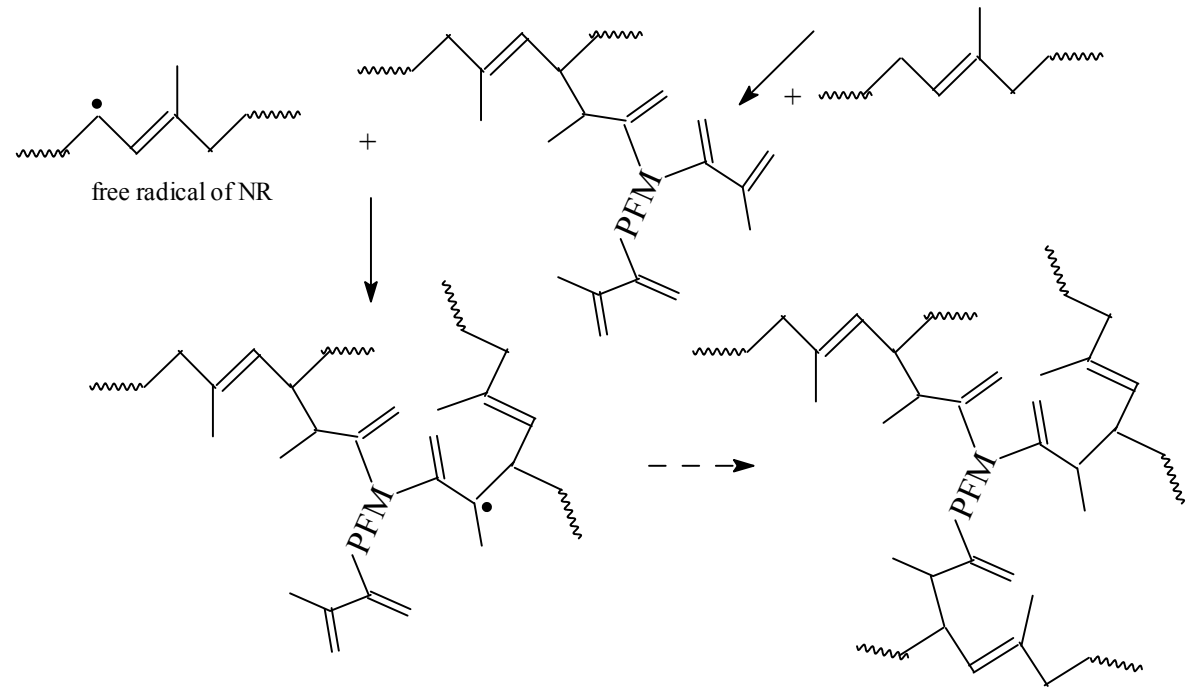

Figure 4. Possible mechanism of NR cross-linking and grafting in the presence of TMPT by EB irradiation. 


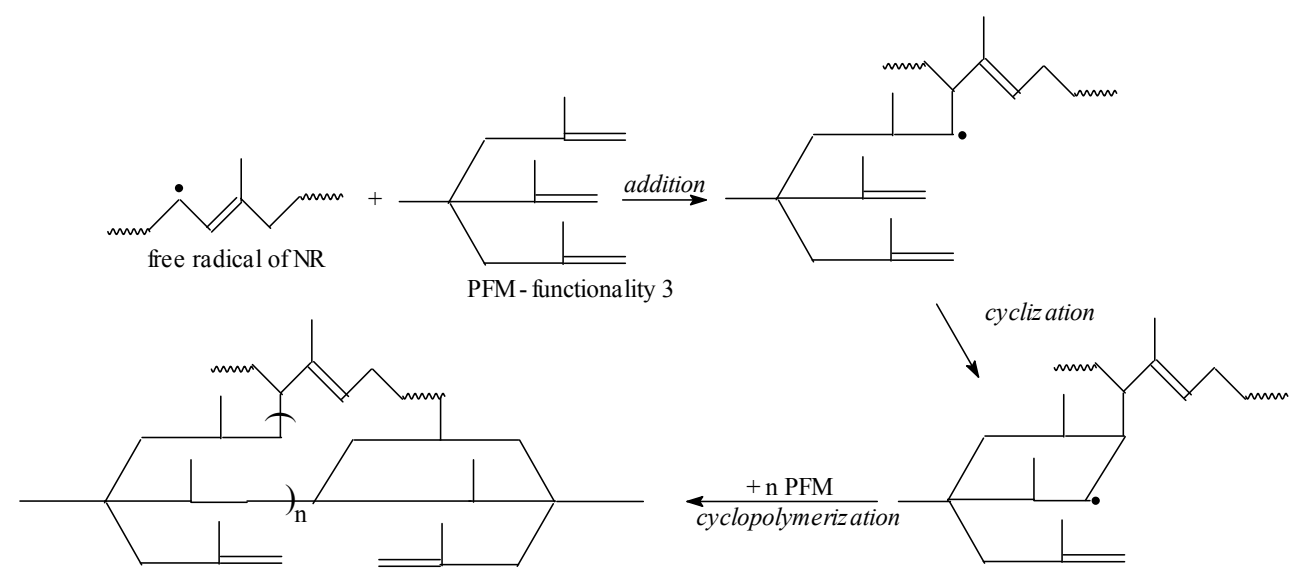

Figure 5. Possible mechanism of TMPT cyclopolymerization on NR.

Once the macro-radical in the NR chain is formed, because of the TMPT presence, a new radical on TMPT is formed. Afterwards, a chain transfer reaction in the presence of NR takes place and leads to the formation of a new NR radical. The same sequence is conducted on the other functional groups of the TMPT, which leads to the formation of a product of cross-linking (Figure 4). On the other hand, after initiating of the reaction and formation of free radicals on NR chain, these PFMs are quickly cross-linked by free radical addition reactions and cyclo-polymerization (Figure 5), forming small vitrified thermo-reactive particles [33-35]. These particles act as multi-modal cross-linking centers, binding a large number of NR chains [36]. We can conclude that the Type I co-agents (TMPT, EDMA or ZDA) are very reactive monomers, favoring addition reactions leading to homo-polymerization and subsequent grafting to polymer chains, through either direct addition reactions or through abstraction/coupling reactions with polymer chains [29]. Regardless of mechanism, the Type I co-agents have increased the cross-link density, as shown in Figure 2.

A possible reaction mechanism for the radiation cross-linking of NR with a Type II co-agent is summarized in Figure 6.

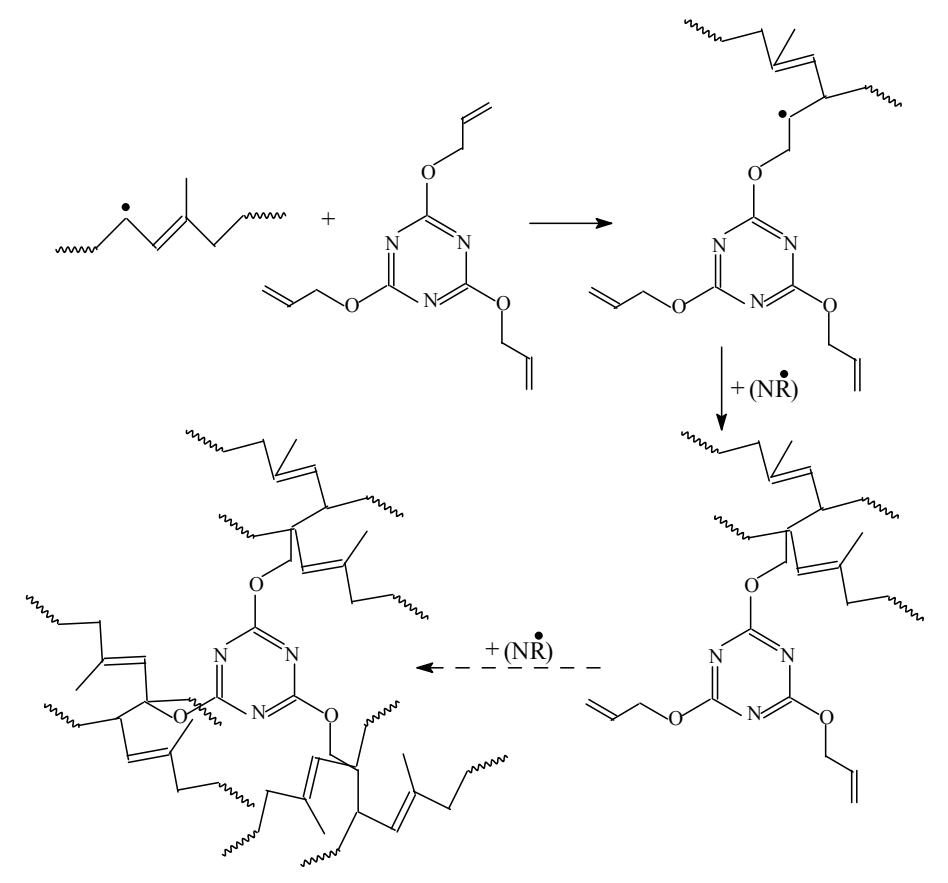

Figure 6. Possible mechanism of NR cross-linking and grafting in the presence of TAC by EB irradiation. 
Generally, the addition of a Type II co-agent had less impact on cross-link density. The addition reactions dominate the cure mechanism, as shown in Figure 6. Homo-polymerization may proceed with a slower rate due to group reactivity and steric hindrance associated with the polymeric form [29].

The termination reactions for both Type I and Type II co-agents can be either disproportionation or combination of radical intermediates, and can also lead to cross-link structures [5]. The above mechanisms explain how the co-agent is incorporated into the network, via its functionalities. In NR, the co-agents of Type I have generated higher cross-link densities than the co-agents of Type II. Compared with the control sample (NR without PFMs), PFMs have created bridges between NR chains, thus contributing to an increase in cross-linking efficiency by generating extra cross-links. More than that, because of the major affinity for radicals, they help to minimize the chain scission and disproportionation reactions. On the other hand, the PFMs can be incorporated into the polymer network either by polymerization with the formation of an interpenetrating network by homo-polymerization of co-agent molecules or by grafting onto the polymer backbone. Probably, the process that takes place in cross-linking process is a combination of the mentioned mechanisms [5].

In order to evaluate quantitatively the cross-linking and chain scission yields of irradiated NR and NR/PFMs samples, plots of $S+S^{1 / 2}$ vs. 1/absorbed dose (D) from the Charlesby-Pinner equation were drawn (Figure 7) [37,38]:

$$
\mathrm{S}+\mathrm{S}^{1 / 2}=\frac{\mathrm{p}_{0}}{\mathrm{q}_{0}}+\frac{2}{\mathrm{q}_{0} \times \mathrm{u}_{\mathrm{w}, 0} \times \mathrm{D}}
$$

where $S$ is the content of soluble fraction (sol), $\mathrm{p}_{0}$ is the average number of main chain scissions per monomer unit and per unit dose, $\mathrm{q}_{0}$ is the proportion of monomer unit cross-linked per unit dose, $\mathrm{u}_{\mathrm{w}, 0}$ is the initial weight-average degree of polymerization, and $\mathrm{D}$ is the irradiation dose or the cross-linking agent concentration (in the case of chemical cross-linking).

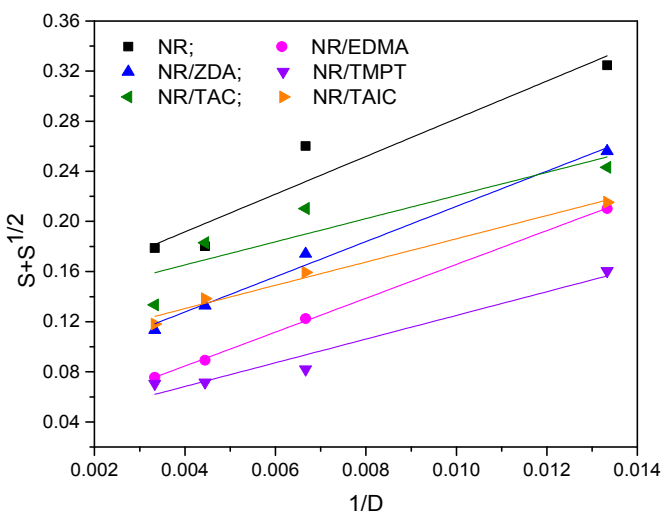

Figure 7. Charlesby-Pinner plots of NR and NR/PFMs samples.

From Figure 7 and Table 3 it can be seen that the addition of PFMs decreases the $\mathrm{p}_{0} / \mathrm{q}_{0}$ ratio from 0.1315 for NR without PFMs samples to 0.0305 for NR/PFMs samples. This is due to a strong cross-linking occurrence in NR because of the addition of TMPT as cross-linker which has a very important role in the acceleration of the cross-linking process by generating many free radicals during irradiation. On the other hand, from Table 3 it can be observed that the values of $\mathrm{p}_{0} / \mathrm{q}_{0}$ ratio for the co-agent of Type II are higher compared with that for the co-agent of Type I, which indicates an easiness of cross-linking. The influence of PFMs on $\mathrm{p}_{0} / \mathrm{q}_{0}$ value for the samples vulcanized with EB is as follows: TMPT > EDMA > ZDA > TAIC > TAC and the results are in a good agreement with those obtained for cross-linking degree. The addition of TMPT (Type I, functionality 3) significantly decreases $\mathrm{p}_{0} / \mathrm{q}_{0}$ value compared with the control samples (NR) and NR/TAC or NR/TAIC samples, but very good values were also obtained for NR/EDMA and NR/ZDA (Type I, functionality 2) samples. Thus, 
by using TMPT as cross-linker, not only is the rate of cure increased but also the cross-link density or state of cure [31], due to the formation of a three-dimensional network structure [32].

Table 3. Compositional characteristics, designation and $\mathrm{p}_{0} / \mathrm{q}_{0}$ ratio for NR and NR/PFMs samples.

\begin{tabular}{ccc}
\hline Samples & Type and Functionality of PFMs & $\mathbf{p}_{\mathbf{0}} / \mathbf{q}_{\mathbf{0}}$ \\
\hline NR & & 0.1315 \\
NR/TAC & $\mathrm{II} / 3$ & 0.1283 \\
NR/TAIC & $\mathrm{II} / 3$ & 0.0934 \\
NR/ZDA & $\mathrm{I} / 2$ & 0.0715 \\
NR/EDMA & $\mathrm{I} / 2$ & 0.0306 \\
NR/TMPT & $\mathrm{I} / 3$ & 0.0305 \\
\hline
\end{tabular}

\subsection{Fourier Transform Infrared Spectroscopy (FTIR)}

Natural rubber is composed of hydrocarbons (89.3 wt \%-92.4 wt \%), proteins (2.5 wt \%-3.5 wt \%) and other ingredients (4.1 wt \%-8.2 wt \%). The main component of NR is cis-1,4-polyisoprene having long chains and a high degree branching, generally associated with the presence of non-hydrocarbon groups distributed along the chains. Figure 8 and Table 4 show the infrared spectra and characteristic infrared bands (observed in the region of $4000 \mathrm{~cm}^{-1}-600 \mathrm{~cm}^{-1}$ ) of natural rubber samples without PFMs irradiated at 75 and $300 \mathrm{kGy}$.
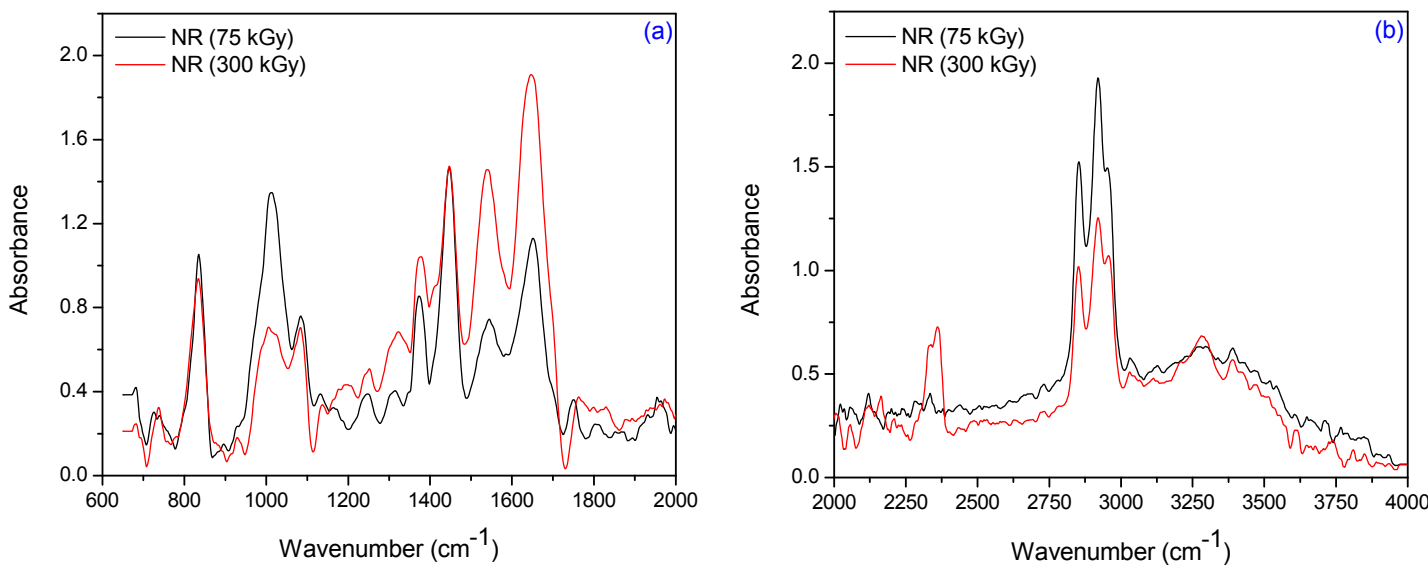

Figure 8. FTIR spectra in the range of (a) $2000 \mathrm{~cm}^{-1}-600 \mathrm{~cm}^{-1}$ and (b) $4000 \mathrm{~cm}^{-1}-2000 \mathrm{~cm}^{-1}$, for NR irradiated at 75 and $300 \mathrm{kGy}$.

Table 4. The mass losses of samples immersed in Water, Sodium hydroxide (1\%), Ethylic alcohol (96\%), Acetic acid (10\%), Sodium chloride $(0.9 \%)$ and Glucose monohydrate $(10 \%)$.

\begin{tabular}{|c|c|c|c|c|c|c|}
\hline $\begin{array}{l}\text { Sample } \\
\text { Type }\end{array}$ & Water & $\begin{array}{c}\text { Sodium Hydroxide } \\
(1 \%)\end{array}$ & $\begin{array}{l}\text { Ethylic Alcohol } \\
(96 \%)\end{array}$ & $\begin{array}{l}\text { Acetic Acid } \\
(\mathbf{1 0} \%)\end{array}$ & $\begin{array}{c}\text { Sodium Chloride } \\
(0.9 \%)\end{array}$ & $\begin{array}{c}\text { Glucose Monohydrate } \\
(10 \%)\end{array}$ \\
\hline \multicolumn{7}{|c|}{ NR 0} \\
\hline 75 kGy & $-0.141 \pm 0.018$ & $0.735 \pm 0.084$ & $-0.561 \pm 0.087$ & $-0.119 \pm 0.011$ & $-0.194 \pm 0.018$ & $-0.149 \pm 0.013$ \\
\hline 150 kGy & $-0.137 \pm 0.015$ & $0.643 \pm 0.134$ & $-0.457 \pm 0.031$ & $-0.11 \pm 0.014$ & $-0.136 \pm 0.017$ & $-0.093 \pm 0.014$ \\
\hline 225 kGy & $-0.13 \pm 0.014$ & $0.222 \pm 0.042$ & $-0.43 \pm 0.033$ & $-0.082 \pm 0.021$ & $-0.111 \pm 0.011$ & $-0.085 \pm 0.017$ \\
\hline 300 kGy & $-0.106 \pm 0.012$ & $0.212 \pm 0.054$ & $-0.432 \pm 0.013$ & $-0.078 \pm 0.015$ & $-0.103 \pm 0.011$ & $-0.073 \pm 0.011$ \\
\hline \multicolumn{7}{|c|}{ NR + TMPT } \\
\hline 75 kGy & $-0.189 \pm 0.021$ & $-0.16 \pm 0.010$ & $-0.451 \pm 0.057$ & $-0.091 \pm 0.011$ & $-0.243 \pm 0.020$ & $-0.077 \pm 0.059$ \\
\hline 150 kGy & $-0.108 \pm 0.026$ & $-0.137 \pm 0.015$ & $-0.262 \pm 0.017$ & $-0.053 \pm 0.012$ & $-0.133 \pm 0.010$ & $-0.034 \pm 0.014$ \\
\hline 225 kGy & $0.103 \pm 0.013$ & $-0.104 \pm 0.015$ & $-0.255 \pm 0.029$ & $-0.033 \pm 0.012$ & $-0.103 \pm 0.013$ & $-0.026 \pm 0.010$ \\
\hline 300 kGy & $-0.104 \pm 0.010$ & $0.075 \pm 0.028$ & $-0.242 \pm 0.010$ & $-0.023 \pm 0.011$ & $-0.093 \pm 0.021$ & $-0.033 \pm 0.011$ \\
\hline \multicolumn{7}{|c|}{ NR + EDMA } \\
\hline 75 kGy & $-0.305 \pm 0.073$ & $0.357 \pm 0.014$ & $-0.52 \pm 0.025$ & $-0.077 \pm 0.048$ & $-0.288 \pm 0.051$ & $-0.208 \pm 0.018$ \\
\hline 150 kGy & $-0.216 \pm 0.032$ & $0.324 \pm 0.324$ & $-0.352 \pm 0.040$ & $-0.072 \pm 0.035$ & $-0.217 \pm 0.026$ & $-0.176 \pm 0.025$ \\
\hline 225 kGy & $-0.197 \pm 0.037$ & $0.376 \pm 0.073$ & $-0.286 \pm 0.033$ & $-0.043 \pm 0.065$ & $-0.165 \pm 0.015$ & $-0.171 \pm 0.048$ \\
\hline 300 kGy & $-0.138 \pm 0.052$ & $0.622 \pm 0.104$ & $-0.284 \pm 0.011$ & $-0.016 \pm 0.049$ & $-0.158 \pm 0.034$ & $-0.137 \pm 0.023$ \\
\hline
\end{tabular}


Table 4. Cont.

\begin{tabular}{|c|c|c|c|c|c|c|}
\hline $\begin{array}{l}\text { Sample } \\
\text { Type }\end{array}$ & Water & $\begin{array}{c}\text { Sodium Hydroxide } \\
(1 \%)\end{array}$ & $\begin{array}{l}\text { Ethylic Alcohol } \\
\qquad(96 \%)\end{array}$ & $\begin{array}{l}\text { Acetic Acid } \\
(10 \%)\end{array}$ & $\begin{array}{c}\text { Sodium Chloride } \\
(0.9 \%)\end{array}$ & $\begin{array}{c}\text { Glucose Monohydrate } \\
(10 \%)\end{array}$ \\
\hline \multicolumn{7}{|c|}{ NR + ZDA } \\
\hline 75 kGy & $-0.285 \pm 0.049$ & $0.438 \pm 0.142$ & $-0.466 \pm 0.069$ & $-0.096 \pm 0.015$ & $-0.292 \pm 0.033$ & $-0.228 \pm 0.014$ \\
\hline 150 kGy & $-0.235 \pm 0.047$ & $0.277 \pm 0.077$ & $-0.448 \pm 0.031$ & $0.055 \pm 0.013$ & $-0.24 \pm 0.029$ & $-0.213 \pm 0.041$ \\
\hline 225 kGy & $-0.204 \pm 0.010$ & $0.155 \pm 0.072$ & $-0.435 \pm 0.068$ & $-0.043 \pm 0.049$ & $-0.188 \pm 0.021$ & $-0.193 \pm 0.021$ \\
\hline 300 kGy & $-0.165 \pm 0.057$ & $0.114 \pm 0.010$ & $-0.421 \pm 0.039$ & $-0.047 \pm 0.016$ & $-0.127 \pm 0.039$ & $-0.109 \pm 0.016$ \\
\hline \multicolumn{7}{|c|}{$\mathrm{NR}+\mathrm{TAC}$} \\
\hline $75 \mathrm{kGy}$ & $-0.511 \pm 0.014$ & $-0.605 \pm 0.029$ & $-1.152 \pm 0.310$ & $-0.592 \pm 0.104$ & $-0.559 \pm 0.054$ & $-0.432 \pm 0.029$ \\
\hline 150 kGy & $-0.441 \pm 0.045$ & $-0.528 \pm 0.069$ & $-1.016 \pm 0.065$ & $-0.562 \pm 0.052$ & $-0.52 \pm 0.038$ & $-0.412 \pm 0.041$ \\
\hline $225 \mathrm{kGy}$ & $-0.417 \pm 0.011$ & $-0.454 \pm 0.045$ & $-0.626 \pm 0.034$ & $-0.256 \pm 0.021$ & $-0.357 \pm 0.032$ & $-0.304 \pm 0.037$ \\
\hline 300 kGy & $-0.352 \pm 0.027$ & $-0.426 \pm 0.041$ & $-0.605 \pm 0.029$ & $-0.248 \pm 0.025$ & $-0.336 \pm 0.014$ & $-0.265 \pm 0.025$ \\
\hline \multicolumn{7}{|c|}{ NR + TAIC } \\
\hline 75 kGy & $-0.614 \pm 0.037$ & $-1.002 \pm 0.098$ & $-0.858 \pm 0.012$ & $-0.541 \pm 0.020$ & $-0.773 \pm 0.059$ & $-0.745 \pm 0.098$ \\
\hline 150 kGy & $-0.485 \pm 0.022$ & $-0.542 \pm 0.025$ & $-0.822 \pm 0.012$ & $-0.429 \pm 0.041$ & $-0.498 \pm 0.069$ & $-0.659 \pm 0.101$ \\
\hline 225 kGy & $-0.481 \pm 0.103$ & $-0.486 \pm 0.053$ & $-0.789 \pm 0.012$ & $-0.408 \pm 0.034$ & $-0.489 \pm 0.021$ & $-0.65 \pm 0.075$ \\
\hline 300 kGy & $-0.477 \pm 0.043$ & $-0.378 \pm 0.093$ & $-0.647 \pm 0.012$ & $-0.315 \pm 0.036$ & $-0.497 \pm 0.026$ & $-0.466 \pm 0.102$ \\
\hline
\end{tabular}

The specific absorption bands of single bonds corresponding to $\mathrm{R}_{2} \mathrm{C}=\mathrm{CH}-\mathrm{R}$ groups are observed at $840 \mathrm{~cm}^{-1}-830 \mathrm{~cm}^{-1}$. These changes occur as a result of elastomer cross-linking and double bonds consuming. The $\mathrm{CH}_{3}$ rocking vibrations occur in the region $1100 \mathrm{~cm}^{-1}-1080 \mathrm{~cm}^{-1}$. The absorption band of $\mathrm{CH}_{3}$ deformation occurs at $1350 \mathrm{~cm}^{-1}-1380 \mathrm{~cm}^{-1}$ and of $\mathrm{CH}_{2}$ asymmetric stretching at $1440 \mathrm{~cm}^{-1}-1460 \mathrm{~cm}^{-1}$. It can be noticed the presence of absorption bands in the spectral region located between 1675 and $1640 \mathrm{~cm}^{-1}$, due to the valence vibration of homogeneous double bonds $\left(v_{\mathrm{C}=\mathrm{C}}\right)$ in the NR structure. The characteristic bands of the saturated aliphatic $\mathrm{sp}^{3} \mathrm{C}-\mathrm{H}$ bonds are observed at $2970 \mathrm{~cm}^{-1}-2830 \mathrm{~cm}^{-1}$, which are assigned to $v_{\mathrm{as}}\left(\mathrm{CH}_{3}\right), v_{\mathrm{as}}\left(\mathrm{CH}_{2}\right)$, and $v_{\mathrm{s}}\left(\mathrm{CH}_{2}\right)$, respectively (as three corresponding bends: $2956 \mathrm{~cm}^{-1}-2957 \mathrm{~cm}^{-1}, 2918 \mathrm{~cm}^{-1}-2919 \mathrm{~cm}^{-1}$, and $2852 \mathrm{~cm}^{-1}-2853 \mathrm{~cm}^{-1}$ ) [39]. The absorption bands with maxima at $3050 \mathrm{~cm}^{-1}-3010 \mathrm{~cm}^{-1}$ correspond to $\mathrm{CH}$ stretching in the $-\mathrm{CH}=\mathrm{CH}_{2}$ group. It is known that the NR contains also other compounds, such as lipids, neutral glycolipids, phospholipids, etc. The absorption bands at $3250 \mathrm{~cm}^{-1}-3300 \mathrm{~cm}^{-1}$ were identified as corresponding to the proteins, monopeptides and dipeptides present in natural rubber [40] and the absorption band at $1730 \mathrm{~cm}^{-1}$ was identified as corresponding to the fatty acid ester groups [41]. Figures 9-11 show the infrared spectra in the region of $4000 \mathrm{~cm}^{-1}-600 \mathrm{~cm}^{-1}$ for natural rubber with PFMs of Type I (EDMA, TMPT and ZDA) irradiated at 75 and $300 \mathrm{kGy}$.
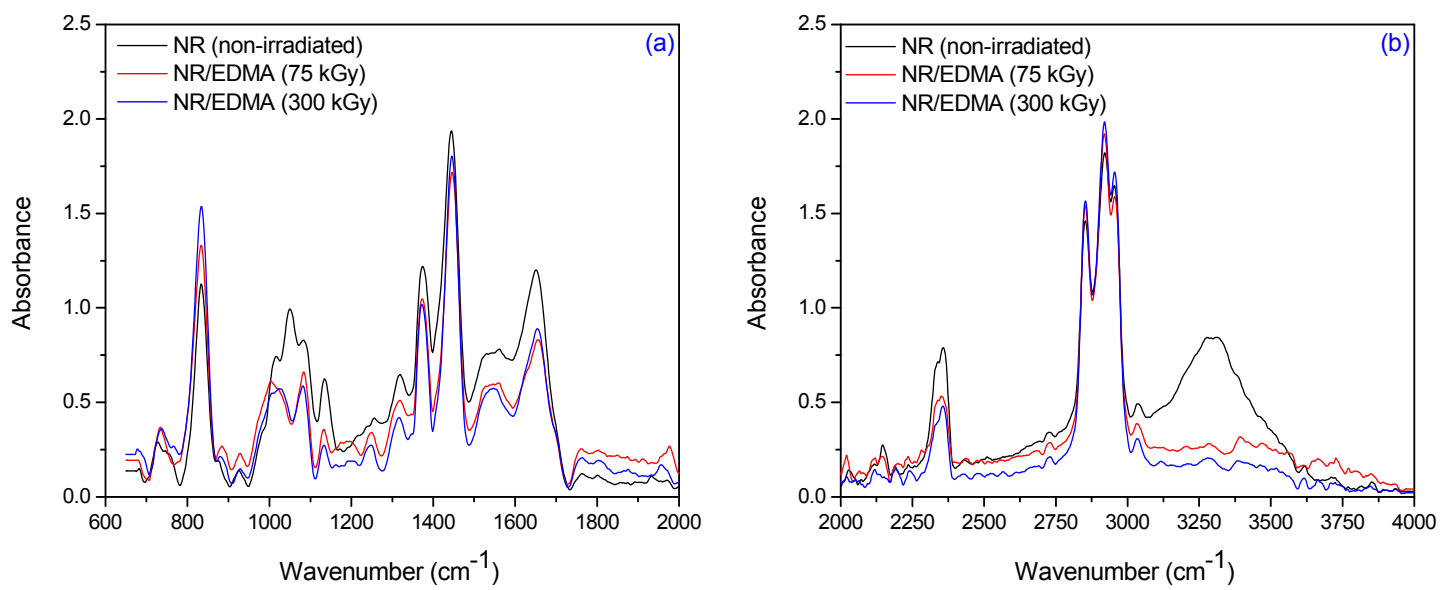

Figure 9. FTIR spectra in the range of (a) $2000 \mathrm{~cm}^{-1}-600 \mathrm{~cm}^{-1}$ and (b) $4000 \mathrm{~cm}^{-1}-2000 \mathrm{~cm}^{-1}$ for NR/EDMA irradiated at 75 and $300 \mathrm{kGy}$. 

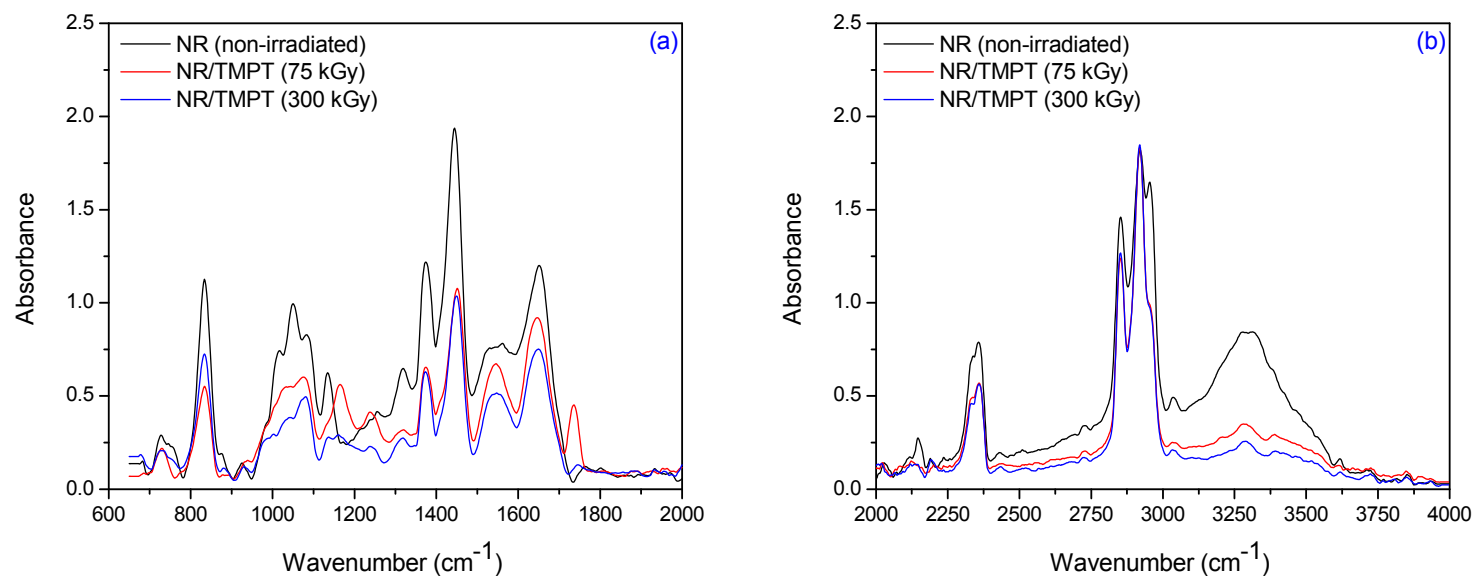

Figure 10. FTIR spectra in the range of (a) $2000 \mathrm{~cm}^{-1}-600 \mathrm{~cm}^{-1}$ and (b) $4000 \mathrm{~cm}^{-1}-2000 \mathrm{~cm}^{-1}$ for NR/TMPT irradiated at 75 and $300 \mathrm{kGy}$.
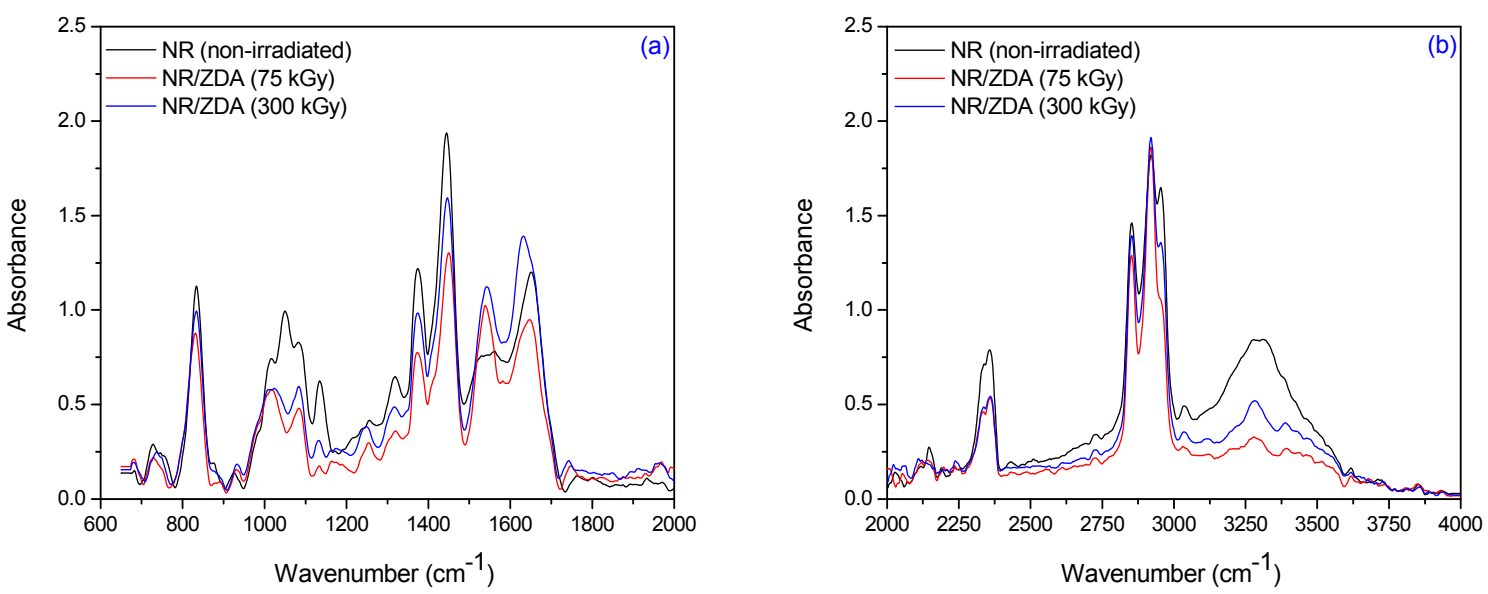

Figure 11. FTIR spectra in the range of (a) $2000 \mathrm{~cm}^{-1}-600 \mathrm{~cm}^{-1}$ and (b) $4000 \mathrm{~cm}^{-1}-2000 \mathrm{~cm}^{-1}$ for NR/ZDA irradiated at 75 and 300 kGy.

For NR/PFMs mixtures, the absorbtion bands are higher than for mixtures without PFMs due to the presence of double bonds in the PFMs structures. The spectrum, of both non-irradiated NR and NR/PFMs samples, exhibits absorption bands at $3040 \mathrm{~cm}^{-1}-3020 \mathrm{~cm}^{-1}$ that correspond to the $\mathrm{CH}$ stretching in the $-\mathrm{CH}=\mathrm{CH}_{2}$ group. Irradiation of the samples up to $75 \mathrm{kGy}$ generates the consumption of the double bonds in NR and PFMs molecules, so that the intensities of these absorption bands decrease. The evidence for methylmethacrylate (MMA) group presence in the PFMs was observed in the range of $1140 \mathrm{~cm}^{-1}-1130 \mathrm{~cm}^{-1}$ due to the $-\mathrm{C}-\mathrm{O}-$ moiety from the ester functional groups of MMA [42]. As shown in Figures 9-11 in samples consisting of NR/Type I PFMs mixtures irradiated at 75 and $300 \mathrm{kGy}$, respectively, this band is reduced or shifted. On the other hand, during the vulcanization by EB irradiation of NR in the presence of Type I co-agent, the NR macroradical is added to the terminal $\mathrm{C}=\mathrm{C}$ link of the co-agent. This is confirmed by the decreasing of the intense absorption bands at $840 \mathrm{~cm}^{-1}-820 \mathrm{~cm}^{-1}$ (=CH- out-of-plane bending) and $1655 \mathrm{~cm}^{-1}-1645 \mathrm{~cm}^{-1}$ $(\mathrm{C}=\mathrm{C}$ stretch $)$ in the spectrum of vulcanized NR containing the co-agents TMPT and ZDA, possibly due to the incorporation of the co-agent to the $\mathrm{C}=\mathrm{C}$ bond of the natural rubber [43]. Moreover, this is confirmed by the presence of the band at $1140 \mathrm{~cm}^{-1}-1130 \mathrm{~cm}^{-1}$ (C-C stretching) that was shifted in the spectrum of the samples containing the TMPT and decreased for samples with EDMA and ZDA, compared with the samples without the co-agent. On the other hand, the intensity of the absorption band at $1760 \mathrm{~cm}^{-1}-1755 \mathrm{~cm}^{-1}$ (ester linkage without the conjugation) is considerably reduced after the controlled cleavage of the ester linkage. The changes produced in the intensities of the 
absorption bands at $1655 \mathrm{~cm}^{-1}-1645 \mathrm{~cm}^{-1}$ (C=C stretch), $1450 \mathrm{~cm}^{-1}-1435 \mathrm{~cm}^{-1}\left(-\mathrm{CH}_{2}\right.$ deformation), and $1380 \mathrm{~cm}^{-1}-1360 \mathrm{~cm}^{-1}\left(\mathrm{CH}_{3}\right.$ asymmetric deformation) could be due to some rearrangements of molecules after cleavage [43]. ZDA is a metallic co-agent (of Type I) that is able to produces both, ionic and covalent cross-links, in the vulcanizate. It has two highly reactive acrylic groups and undergoes addition reaction followed by the abstraction with the rubber [43]. When the ZDA is incorporated, some additional bands appear in the spectrum and others are modified. After irradiation, the intensity of the absorption band due to the $C=C$ stretch $\left(1655 \mathrm{~cm}^{-1}-1645 \mathrm{~cm}^{-1}\right)$ is reduced, which confirms the addition of the ZDA into the vulcanizate [43]. The intensity of band at $1450 \mathrm{~cm}^{-1}-1435 \mathrm{~cm}^{-1}$ $\left(-\mathrm{CH}_{2}\right.$ deformation) decreased and a new band appears at $1545 \mathrm{~cm}^{-1}-1535 \mathrm{~cm}^{-1}$ (asymmetric stretching of a strongly coupled $\mathrm{C}-\mathrm{O}$ group of carboxylate anion) [43].

Figures 12 and 13 show the infrared spectra of natural rubber without PFMs of Type II (TAC and TAIC) irradiated at 75 and $300 \mathrm{kGy}$, respectively. For the samples having TAC and TAIC, the absorption bands at $840-830,1025-1010,1140-1120$ and $1660-1640 \mathrm{~cm}^{-1}$ (=CH- out-of-plane bending, $\mathrm{C}-\mathrm{C}$ stretch and $\mathrm{C}=\mathrm{C}$ stretching, respectively) are considerably modified. If the co-agent is grafted into the polymer network, there should be an increase in the intensity of absorption band due to the $\mathrm{C}-\mathrm{C}$ stretch (1025-1010 and 1140-1120 $\mathrm{cm}^{-1}$ ) and this is observed for NR/TAC samples [43].
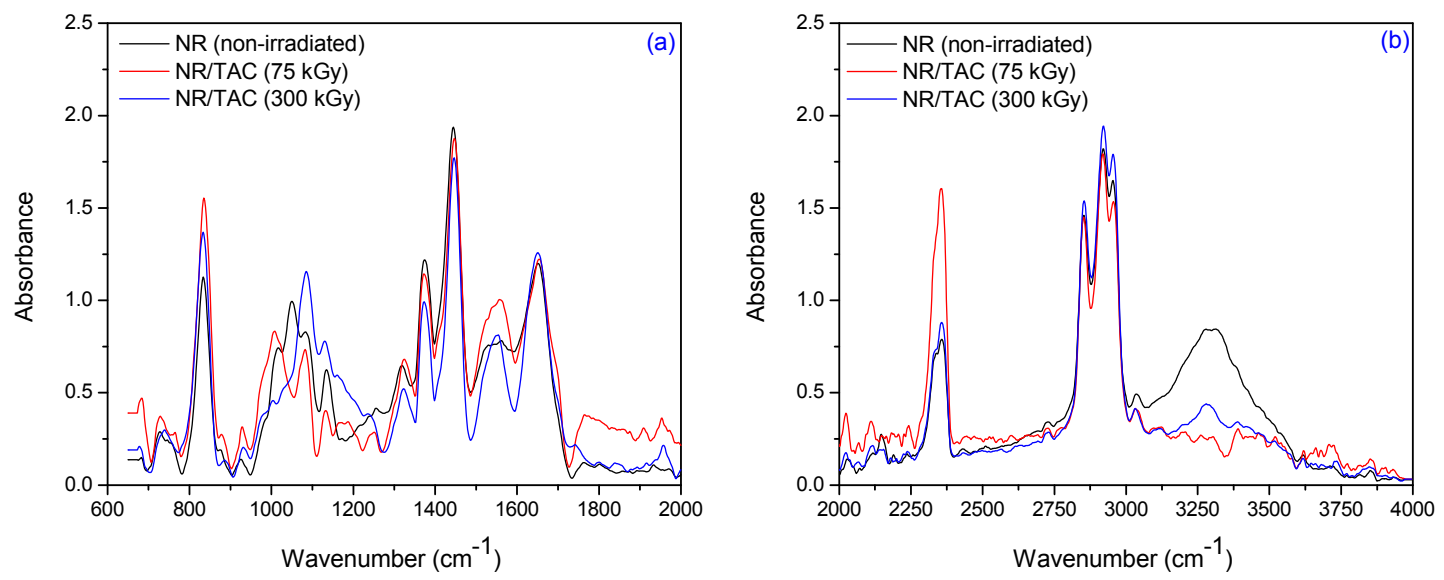

Figure 12. FTIR spectra in the range of (a) $2000 \mathrm{~cm}^{-1}-600 \mathrm{~cm}^{-1}$ and (b) $4000 \mathrm{~cm}^{-1}-2000 \mathrm{~cm}^{-1}$ for NR/TAC samples, irradiated at 75 and $300 \mathrm{kGy}$.
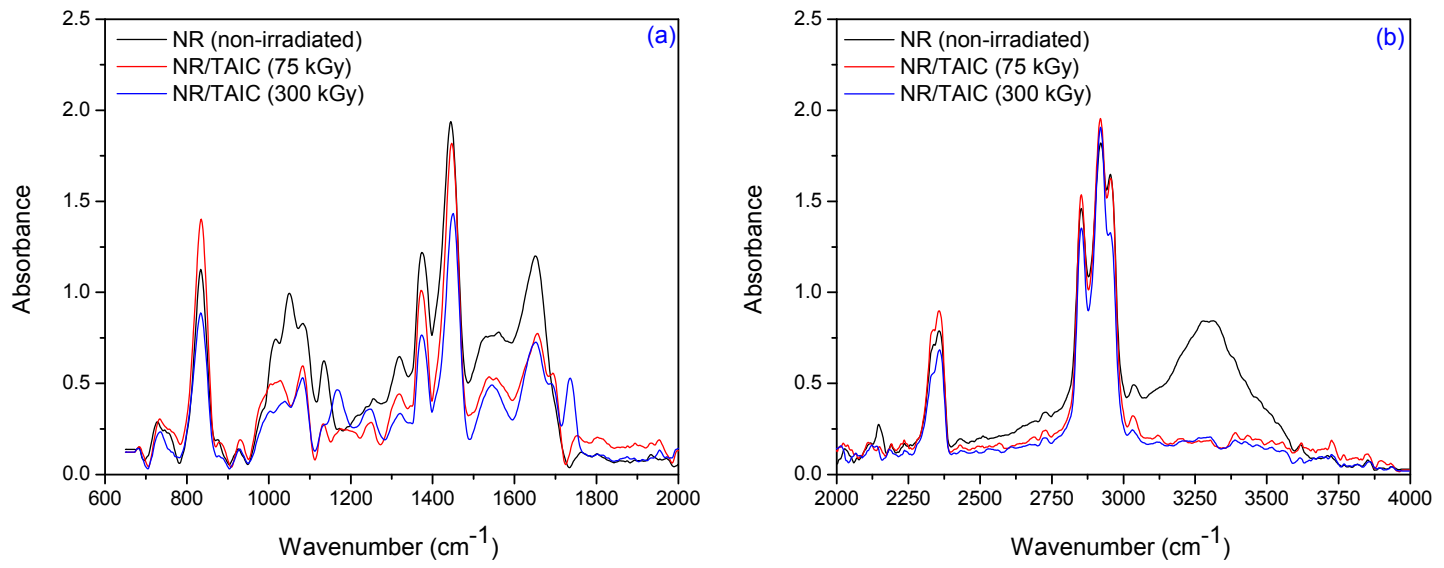

Figure 13. FTIR spectra in the range of (a) $2000 \mathrm{~cm}^{-1}-600 \mathrm{~cm}^{-1}$ and (b) $4000 \mathrm{~cm}^{-1}-2000 \mathrm{~cm}^{-1}$ for NR/TAIC samples, irradiated at 75 and $300 \mathrm{kGy}$.

The free radicals produced by EB can abstract the hydrogen from the polymer to form polymer macroradical or can facilitate the isomerization of co-agent triallylcyanurate to triallylisocyanurate. Because most of the radicals are consumed for isomerization, even if $\mathrm{C}-\mathrm{C}$ bonds are formed by the 
recombination of polymer radical, the percentage of $\mathrm{C}-\mathrm{C}$ formed, and consequently, the intensity of band, is lower. This is supported by the band at $1750 \mathrm{~cm}^{-1}-1730 \mathrm{~cm}^{-1}$ (C=O group) in the spectrum of the sample containing TAC [43]. In addition, the cross-linking of NR with TAC and TAIC after irradiation is confirmed by the presence of the bands at 1565-1555 and 1330-1320 $\mathrm{cm}^{-1}$. The intensity of the band at $1565 \mathrm{~cm}^{-1}-1555 \mathrm{~cm}^{-1}$ is due to the presence of the triazine ring (quadrant stretching) with the benzene structure (or due to the presence of cyclic $>\mathrm{C}=\mathrm{N}$ groups) and the absorption at $1330 \mathrm{~cm}^{-1}-1320 \mathrm{~cm}^{-1}$ to the presence of $\mathrm{C}-\mathrm{O}$ stretching vibrations [44].

\subsection{Scanning Electron Microscopy (SEM)}

The scanning electron micrographs of cryofractured surfaces of NR/PFMs are presented in Figure 14a-f and clearly show the differences in their surface morphology. Normally, both linear and cross-linked NR has a smooth and wave-like morphology that is independent of the cross-linked density. For the samples having the highest cross-linked density, a more compact and small phase domain was observed. The decreasing of the cross-link density clearly shows smooth and wave-like morphologies. At the lowest cross-link density the dispersed fibrils in the continuous cross-linked NR phase appear [45].
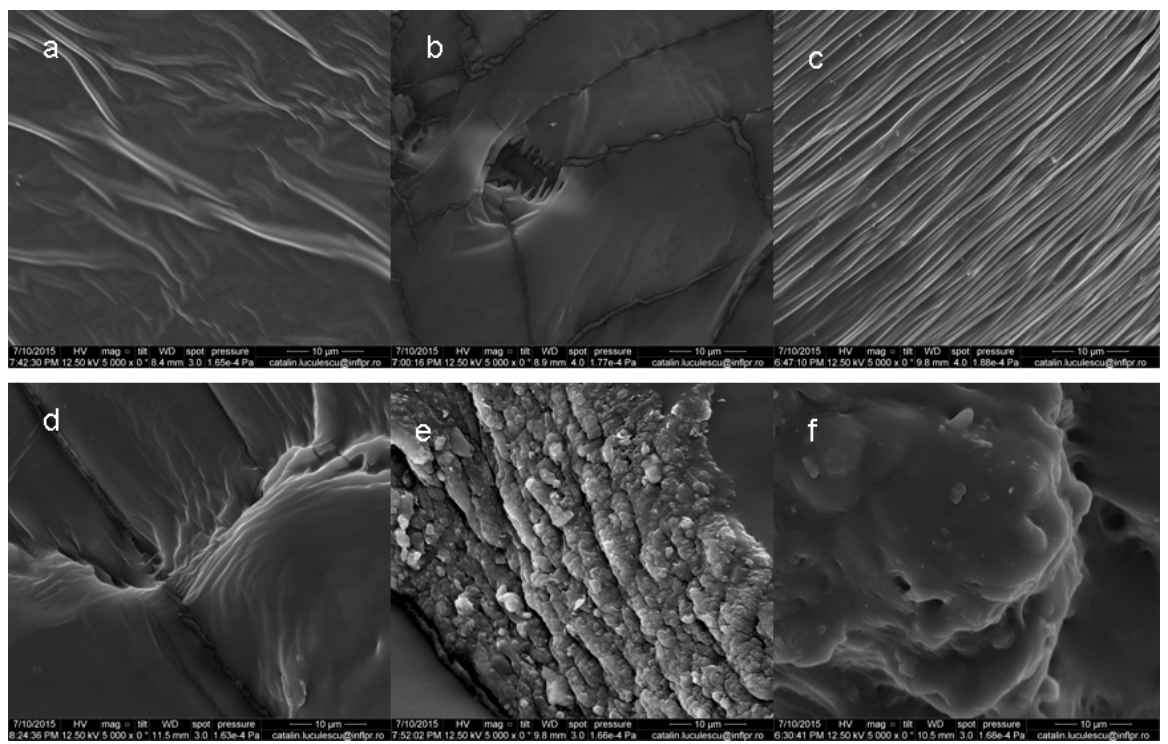

Figure 14. Surface morphology of: (a) NR; (b) NR/EDMA; (c) NR/ZDA; (d) NR/TMPT; (e) NR/TAC; and (f) NR/TAIC samples, irradiated at $300 \mathrm{kGy}$.

For NR and NR/ZDA samples, the surface appears to be smoother, without fibrils formation. In addition, for NR/EDMA and NR/TMPT samples, the surfaces appear to be smoother, but show an appearance similar to a mosaic pattern. According to Mateev and Karageorgiev [46], this is the result of a transition from plastic into brittle type microdestruction. The transition is due to the radiation-induced cross-linking of the macromolecular chains, which takes place predominantly in the intercrystalline amorphous regions [47]. We can say that the morphology becomes fixed, characterised by the formations of strong interpenetrating networks [47]. The surfaces of NR/TAC and NR/TAIC samples appear to be rougher and more brittle compared with other samples, showing also cavities and micro cracks that can be attributed to the degradation during irradiation [48]. In all samples, the dark spots indicate the empty holes left behind by the NR after dissolving in toluene [47].

\subsection{Absorption Tests on Different Aqueous Solutions}

The products based on rubber are widely used in pharmaceutical processing industry or for food processing equipment and the most common products are gaskets, conveyor belts, hoses and 
rubber seals. Rubber is normally chosen because of its process ability, properties and its price [49]. The elasticity, which allows good sealing and resealing properties, low gas and water permeability, excellent oil resistance, good physical and chemical properties, low level of migrating substances from the rubber products, and compatibility with food, water, pharmaceutical and cosmetic products as well as the compliance with stringent regulatory requirements, are essential for the use of rubber in the mentioned fields and in many others [1]. A prerequisite for polymers use in contact with food is the compliance with food regulations. Many countries have national positive lists containing the materials permitted for being in contact with food: in USA, FDA (Food and Drug Administration) parts 170 to 199; in Germany, BgVV (German Federal Institute for Consumer Health and Veterinary Medicine) Recommendation XXI; in France, issued by the Ministry for Health published in "Le Journal Officiel de la Republique Francaise" as "L'Arrete du 9 Novembre 1994; in Netherlands, "Verpakkingen en gebruiksartikelenbesluit" (Warenwet) Chapter III; and, in United Kingdom, Statutory Instrument 1987 No. 1523, "Materials and Articles in Contact with Foodstuffs" [1].

In the cross-linking process, in order to achieve the required physical and chemical properties but with respect for national regulations concerning the compliance with food or other products for human use, the polymers and rubbers are mixed with proper fillers and plasticizers. If these chemical constituents are not well selected, they might be harmful to human's health. Carbon black is the predominantly used as filler for the obtaining of compounds based on NR that come into contact with food or potable water and for seals in the pharmaceutical and cosmetic industries. Until now, for food applications, most furnace blacks are considered safe. However, according to the newest food regulations, the type and the amount of carbon black is strictly limited [1] because carbon black itself is a group 2B carcinogen and leads to lung cancer [49,50]. However, during liquid transfer, especially for milk and edible oil, the filler content in rubber has to be lower than $10 \%$ according to FDA regulations (e.g., [49]). Presently, most of the plasticizers used to facilitate the processing of rubber compounds are undesirable for food, potable water and pharmaceutical applications. Because of their low molecular weight in comparison with the polymer, they can be easily extracted in contact with food and also during the sterilization process or extraction tests [1]. If the percent of plasticizers used in rubber products is up to $30 \%$, the contamination of food or other products for human use with phthalates that are strongly carcinogens [51,52] can appear [49]. The choice of the vulcanization system depends on the application of the final product. In rubber products intended for contact with food and milk, sulfur and sulfur donor vulcanization systems are usually used, while for pharmaceutical applications and potable water, both peroxide- and sulfur-based systems are used. It is very difficult to discuss the effect of the curing system and to recommend the optimum one because of the variety of the vulcanization systems used now and because of their complexity. The accelerators usually used may remain unreacted or may form byproducts, some of which may migrate in to food and may be dangerous for human health [1].

Different aqueous solution absorption tests were made according with SR ISO 1817:2015 in order to establish the solutions absorption degree in elastomers samples and the effects of the solutions on the NR/PFMs samples. The chosen aqueous solutions are widely used in food, pharmaceutical and cosmetic industries and their concentrations were chosen taking into account the requirements of the same standard: sodium hydroxide $(\mathrm{NaOH}) 1 \%$, ethyl alcohol (ethanol) $96 \%$, acetic acid $10 \%$, physiological serum (sodium chloride) $0.9 \%$ and glucose (glucose monohydrate) $10 \%$. Before the immersion, the samples were dried in a laboratory oven to constant mass and weighed. Then were immersed in the aqueous solutions for $22 \mathrm{~h}$ at the temperature of $23 \pm 2{ }^{\circ} \mathrm{C}$. After that, the samples were removed from the solutions, wiped using filter paper and reweighed one by one, in order to establish the mass growth.

The results of the water and water solutions uptake tests on NR/PFMs samples are presented in Figure 15a-f, as a function of PFMs type and absorbed dose used for elastomers obtaining. 

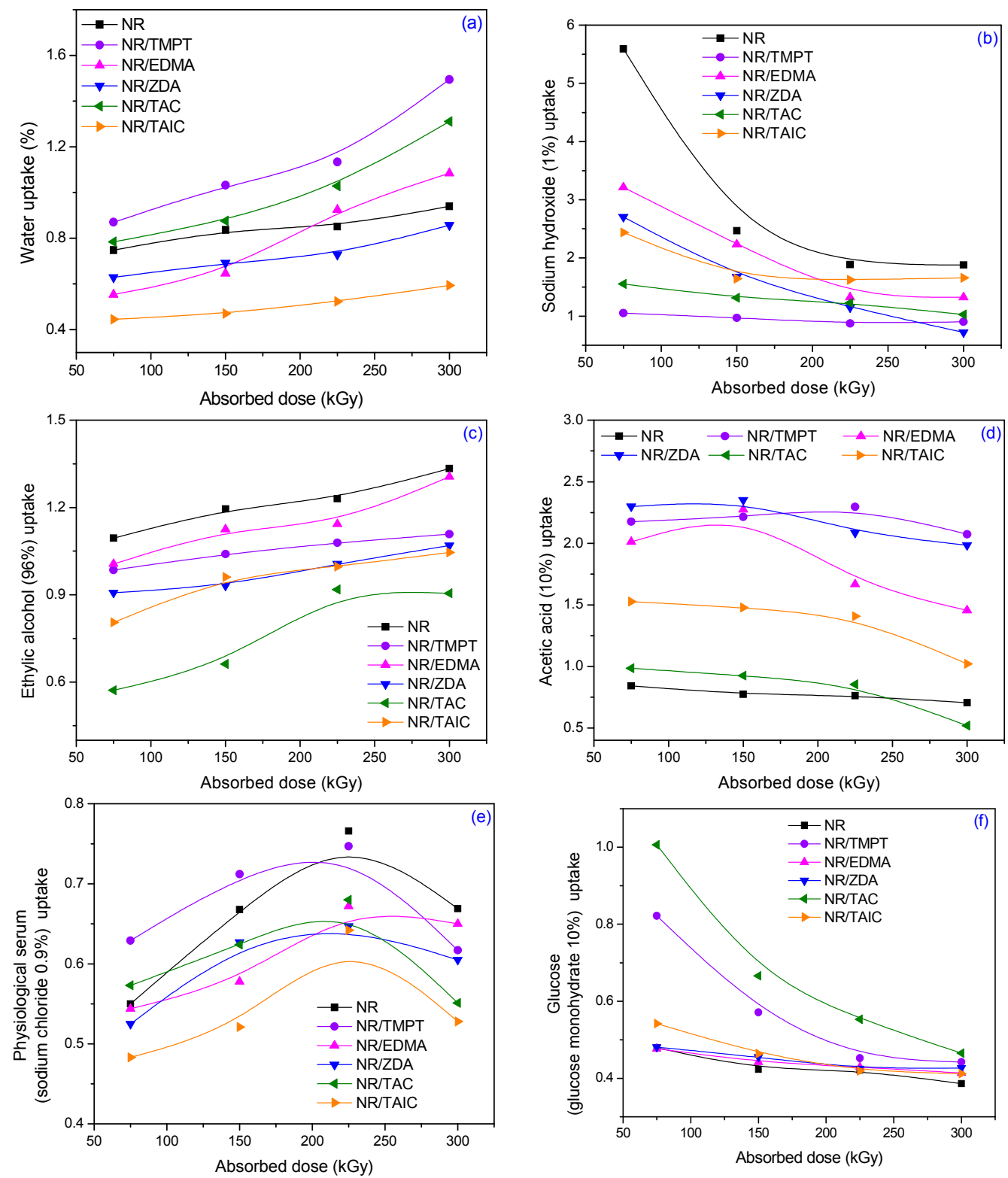

Figure 15. Aqueous solutions uptakes depending on the PFMs type and absorbed dose at $23 \pm 2{ }^{\circ} \mathrm{C}$ in: (a) water; (b) sodium hydroxide (1\%); (c) ethylic alcohol (96\%); (d) acetic acid (10\%); (e) physiological serum (sodium chloride $0.9 \%$ ); and (f) glucose (glucose monohydrate $10 \%$ ).

The standard mentioned above, establishes the mass variation in the case of the immersion in some commonly used solutions. For example, the accepted mass variations are from $-2 \%$ to $6 \%$ in the case of acetic acid using, from $-2 \%$ to $4 \%$ for sodium hydroxide and from $-2 \%$ to $+7 \%$ for ethyl alcohol. In Figure 15b-d it can be seen that maximum mass variation were $2.5 \%$ for acetic acid, $3.3 \%$ for sodium hydroxide and $1.5 \%$ for ethyl alcohol. All of the above-mentioned percentages are included in the intervals recommended by the Romanian standard for the used solutions. For water, physiological serum and glucose, the standard does not have recommendations, but, as it can be seen in Figure 15e,f, the mass variations were less than $1.5 \%$ for water, less than $0.8 \%$ for physiological serum and less than $1 \%$ for glucose. In Table 4 are presented the results of the tests made in order to establish the mass losses of all obtained composites and immersed in the solutions specified above.

The results were obtained by reweighing the samples dried until constant mass for $24 \mathrm{~h}$ at $80{ }^{\circ} \mathrm{C}$. It is easy to observe that the mass losses are up to $-2 \%$, the maximum admitted by the 
specified standard. Moreover, NR itself and mixed with two PMs having functionality of type 2 (NR/EDMA and NR/ZDA) present very low mass losses. Those results indicate that samples are not dissolvable in the specified solutions, so the obtained composites can be used in food, pharmaceutical or cosmetic industries.

\section{Conclusions}

New elastomeric materials based on natural rubber and polyfunctional monomers (TMPT, ZDA, EDMA, TAC, and TAIC) were obtained by electron beam irradiation in the range of $75 \mathrm{kGy}-300 \mathrm{kGy}$. Natural rubber becomes more sensitive to radiation dose by the addition of the polyfunctional monomers. The cross-link density is significantly increased and the influence of the polyfunctional monomers on this parameter was as follows: TMPT $>$ EDMA $>$ ZDA $>$ TAC $>$ TAIC. The addition of TMPT (Type I, functionality 3) significantly increases the cross-link density compared with the control samples (NR) and other PFMs. The addition of a Type II co-agent had less impact on cross-link density. NR/PFMs mixtures were investigated by FTIR Spectroscopy in the range of $4000 \mathrm{~cm}^{-1}-600 \mathrm{~cm}^{-1}$ and the changes in chemical structure highlighted the presence of PFMs in the NR structure. The samples morphology was investigated by SEM technique. Samples having the highest cross-linked density presented a more compact and small phase domain. The decreasing of the cross-link density clearly shows smooth and wave-like morphologies. At the lowest cross-link density, the dispersed fibrils in the continuous cross-linked NR phase appeared. Because products based on rubber are widely used in food, cosmetic and pharmaceutical industries, different aqueous solutions frequently used were tested according to SR ISO 1817:2015 from the point of view of absorption and mass loss. Analyzed samples have presented mass losses up to $-2 \%$ and the absorptions up to $3 \%$ (except NR itself).

Acknowledgments: The researches were financed by the Romanian program "LAPLAS IV" No. 4N/3.03.2016.

Author Contributions: Gabriela Craciun analyzed the data and wrote the paper; Elena Manaila performed the experiments, analyzed the data and contributed to the paper writing; Maria Daniela Stelescu has contributed with the analysis tools.

Conflicts of Interest: The authors declare no conflict of interest.

\section{References}

1. De Coster, N.; Magg, H. NBR in contact with food, potable water, pharmaceutical and cosmetic applications. Kautsch. Gummi Kunstst. 2003, 56, 405-411.

2. Basfar, A.A.; Abdel-Aziz1, M.M.; Mofti, S. Influence of dierent curing systems on the physico-mechanical properties and stability of SBR and NR rubbers. Radiat. Phys. Chem. 2002, 63, 81-87. [CrossRef]

3. Milani, G.; Hanel, T.; Donetti, R.; Milani, F. A closed form solution for the vulcanization prediction of NR cured with sulphur and different accelerators. J. Math. Chem. 2015, 53, 975-997. [CrossRef]

4. Fishbein, L. Chemicals used in the rubber industry: An overview. Scand. J. Work Environ. Health 1983, 9, 7-14. [PubMed]

5. Alvarez Grima, M.M. Novel Co-Agents for Improved Properties in Peroxide Cure of Saturated Elastomers. Ph.D. Thesis, University of Twente, Enschede, The Netherlands, 2007.

6. Dluzneski, P.R. Peroxide vulcanization of elastomers. Rubber Chem. Technol. 2001, 74, 451-492. [CrossRef]

7. Pire, M.; Oikonomou, E.K.; Imbernon, L.; Lorthioir, C.; Iliopoulos, I.; Norvez, S. Crosslinking of epoxidized natural rubber by dicarboxylic acids: An alternative to standard vulcanization. Macromol. Symp. 2013, 331, 89-96. [CrossRef]

8. Pire, M.; Norvez, S.; Iliopoulos, I.; Rossignol, B.; Leibler, L. Dicarboxylic acids may compete with standard vulcanisation processes for crosslinking epoxidised natural rubber. Compos. Interfaces 2014, 21, 45-50. [CrossRef]

9. MGM Rubber Company-Research and Development, Electron Beam Radiation Technology for Curing. 2007. Available online: http:/ / www.mgmrc.com/rd-news/latest-technologies (accessed on 5 July 2016). 
10. Manaila, E.; Stelescu, M.D.; Craciun, G. Aspects regarding radiation crosslinking of elastomers. In Advanced Elastomers-Technology, Properties and Applications; Boczkowska, A., Ed.; InTech: Rijeka, Croatia, 2012; pp. 3-34.

11. Gehman, S.D. Network chain distribution and strength of vulcanizates. Rubber Chem. Technol. 1969, 42, 659-665. [CrossRef]

12. Tobolsky, A.V.; Lyons, P.F. Tensile strength of rubbers. J. Polym. Sci. Part A-2 Polym. Phys. 1968, 6, 1561-1566. [CrossRef]

13. Manaila, E.; Craciun, G.; Stelescu, M.D.; Ighigeanu, D.; Ficai, M. Radiation vulcanization of natural rubber with polyfunctional monomers. Polym. Bull. 2014, 71, 57-82. [CrossRef]

14. Youm, J.S.; Kim, J.C.; Yang, K.S. Elastic property of polyolefin elastomer film cross linked by electron beam irradiation. Fibers Polym. 2012, 13, 1165-1169. [CrossRef]

15. Drobny, J.G. Ionizing Radiation and Polymers: Principles, Technology and Applications, 1st ed.; Elsevier/William Andrew: Norwich, NY, USA, 2012; pp. 88-91.

16. Endstra, W.C. Application of co-agents for peroxide cross-linking. Kautsch. Gummi Kunstst. 1990, 43, 790-793.

17. Dikland, H.G.; Ruardy, T.; Van der Does, L.; Bantjes, A. New coagents in peroxide vulcanization of EPM. Rubber Chem. Technol. 1993, 66, 693-711. [CrossRef]

18. Chaiear, N. Health and Safety in the Rubber Industry; SMITHERS RAPRA: Shropshire, UK, 2001; pp. 102-103.

19. Smoke, T.; Smoking, I. IARC monographs on the evaluation of carcinogenic risks to humans. In Silica, Some Silicates, Coal Dust and Para-Aramid Fibrils; World Health Organization, International Agency for Research on Cancer (IARC): Lyon, France, 1997; Volume 68, pp. 380-385. Available online: https:/ /monographs.iarc. fr/ENG/Monographs/vol68/mono68.pdf (accessed on 18 September 2014).

20. Beliczky, L.S.; Fajen, J. Rubber industry. General profile. In Encyclopaedia of Occupational Health and Safety, 4th ed.; Stellman, J.M., Ed.; International Labor Organization: Geneva, Switzerland, 1998; Volume 3, pp. 80.1-80.3.

21. Marshall, R. Cleland, Industrial applications of electron accelerators-Ion beam applications. In Proceedings of the CERN Accelerator School/Small Accelerator Course, Zeegse, The Netherlands, 24 May-2 June 2005.

22. Manaila, E.; Stelescu, M.D.; Craciun, G.; Ighigeanu, D. Wood sawdust/natural rubber ecocomposites cross-linked by electron beam irradiation. Materials 2016, 9, 503. [CrossRef]

23. Lopez-Manchado, M.A.; Herrero, B.; Arroyo, M. Preparation and characterization of organoclay nanocomposites based on natural rubber. Polym. Int. 2003, 52, 1070-1077. [CrossRef]

24. Chenal, J.M.; Chazeau, L.; Guy, L.; Bomal, Y.; Gauthier, C. Molecular weight between physical entanglements in natural rubber: A critical parameter during strain-induced crystallization. Polymer 2007, 48, 1042-1046. [CrossRef]

25. Stelescu, M.D. Characteristics of silicone rubber blends. Leather Footwear J. 2010, 10, 51-58.

26. Ratnam, C.T.; Nasir, M.; Baharin, A.; Zaman, K. Electron beam irradiation of epoxidized natural rubber. Nucl. Instrum. Methods B 2000, 171, 455-464. [CrossRef]

27. Muhammad, N.H.; Abdullah, I.; Mohd, D.H. Effect of electron beam irradiation on natural rubber/linear low density polyethylene blends with m-phenylenebismaleimide. Sains Malays. 2011, 40, 685-689.

28. Yasin, T.; Ahmed, S.; Ahmed, M.; Yoshii, F. Effect of concentration of polyfunctional monomers on physical properties of acrylonitrile-butadiene rubber under-electron beam irradiation. Radiat. Phys. Chem. 2005, 73, 155-158. [CrossRef]

29. Henning, S.K.; Boye, W.M. Fundamentals of curing elastomers with peroxides and coagents II: Understanding the relationship between coagent and elastomer. Rubber World 2009, 240, 31-39.

30. Henning, S.K.; Costin, R. Fundamentals of curing elastomers with peroxides and coagents I: Coagent structure-Property relationships. In Proceedings of the Technical Meeting of the Rubber Division, American Chemical Society, San Antonio, TX, USA, 16-18 May 2005; pp. 1-18.

31. Henning, S.K. The use of coagents in the radical cure of elastomers. In Proceedings of the 56th International Wire \& Cable Symposium, Lake Buena Vista, FL, USA, 11-14 November 2007; pp. 587-593.

32. Manshaie, R.; Khorasani, S.N.; Veshare, S.J.; Abadchi, M.R. Effect of electron beam irradiation on the properties of natural rubber (NR)/styrene-butadiene rubber (SBR) blend. Radiat. Phys. Chem. 2011, 80, 100-106. [CrossRef] 
33. Dikland, H.G.; Vanderdoes, L.; Bantjes, A. FT-IR spectroscopy, a major tool for the analysis of peroxide vulcanization processes in the presence of coagents. I. mechanism of EPM peroxide vulcanization with aromatic bis(Allyl)esters as coagents. Rubber Chem. Technol. 1993, 66, 196-212. [CrossRef]

34. Murgic, Z.H.; Jelenic, J.; Murgic, L. The mechanism of triallylcyanurate as a coagent in EPDM peroxide vulcanization. Polym. Eng. Sci. 1998, 38, 689-692. [CrossRef]

35. Tikku, V.K.; Biswas, G.; Despande, R.S.; Majali, A.B.; Chaki, T.K.; Bhowmich, A.K. Electron beam initiated grafting of trimethylolpropane trimethacrylate onto polyethylene-Structure and properties. Radiat. Phys. Chem. 1995, 45, 829-833. [CrossRef]

36. Van Duin, M. Chemistry of EPDM cross-linking. Kautch. Gummi Kunstst. 2002, 55, 150-156.

37. Shyichuk, A.; Tokaryk, G. A comparison of methods to determination of macromolecule crosslinking yield from gel fraction data. Polimery 2005, 50, 219-221.

38. Charlesby, A.; Pinner, S.H. Analysis of the solubility behaviour of irradiated polyethylene and other polymers. Proc. R Soc. A Math. Phys. Eng. Sci. 1959, 249, 367-386. [CrossRef]

39. Ali, A.M.M.; Subban, R.H.Y.; Bahron, H.; Winie, T.; Latif, F.; Yahya, M.Z.A. Grafted natural rubber-based polymer electrolytes: ATR-FTIR and conductivity studies. Ionics 2008, 14, 491-500. [CrossRef]

40. Aik-Hwee, E.; Tanaka, Y.; Seng-Neon, G. FTIR studies on amino groups in purified Hevea rubber (short communication). J. Nat. Rubber Res. 1992, 7, 152-155.

41. Chaikumpollert, O.; Yamamoto, Y.; Suchiva, K.; Kawahara, S. Protein-free natural rubber. Colloid Polym. Sci. 2012, 290, 331-338. [CrossRef]

42. Watcharakul, N.; Poompradub, S.; Prasassarakich, P. In situ silica reinforcement of methyl methacrylate grafted natural rubber by sol-gel process. J. Sol-Gel. Sci. Technol. 2011, 58, 407-418. [CrossRef]

43. Rajan, R.; Varghese, S.; George, K.E. Role of coagents in peroxide vulcanization of natural rubber. Rubber Chem. Technol. 2013, 86, 488-502. [CrossRef]

44. Shmakova, N.A.; Feldman, V.I.; Sukhov, F.F. IR spectroscopic study of chemical transformations upon irradiation of the poly(vinyl chloride)-triallyl cyanurate system. High Energy Chem. 2001, 35, 224-228. [CrossRef]

45. Pichayakorn, W.; Suksaeree, J.; Boonme, P. Chapter 13: Blends and IPNs of natural rubber with acrylic plastics. In Natural Rubber Materials, 2013 ed.; Thomas, S., Rajisha, K.R., Maria, H.J., Chan, C.H., Pothen, L.A., Eds.; Royal Society of Chemistry Publications: Cambridge, UK, 2014; Volume 1, p. 312.

46. Mateev, M.; Karageorgiev, S. Electron microscopy analysis of the effect of EB irradiation on the macromolecular structure and crosslinking parameters in LDPE films. Radiat. Phys. Chem. 1996, 48, 443-448. [CrossRef]

47. Dahlan, H.M.; Khairul Zamana, M.D.; Ibrahim, A. Liquid natural rubber (LNR) as a compatibiliser in NR/LLDPE blendsFII: The eects of electron-beam (EB) irradiation. Radiat. Phys. Chem. 2002, 64, 429-436. [CrossRef]

48. Ratnam, C.T.; Mohamad, Z.; Siddiqui, M.K. Chapter 12: Radiation processing of natural rubber with vinyl plastics. In Natural Rubber Materials, 2013 ed.; Thomas, S., Rajisha, K.R., Maria, H.J., Chan, C.H., Pothen, L.A., Eds.; Royal Society of Chemistry Publications: Cambridge, UK, 2014; Volume 1, p. 296.

49. Ng, M.X.; Ong, S.P.; Chin, N.L.; Chuah, L.A.; Law, C.L. Review of food toxicological issues associated in rubber products. In Proceedings of the 3rd International Symposium on Processing of Foods, Vegetables and Fruits (ISPFVF 2014), Kuala Lumpur, Malaysia, 11-13 August 2014; pp. 1-7.

50. Kuempel, E.D.; Sorahan, T. Identification of Research Needs to Resolve the Carcinogenicity of High-Priority IARC Carcinogens; IARC Technical Publication No. 42; International Agency for Research on Cancer: Lyon, France, 2010, pp. 61-72. Available online: https://monographs.iarc.fr/ENG/Publications/techrep42/TR42-Full.pdf (accessed on 10 September 2016).

51. Cao, X.L. Phthalate esters in foods: Sources, occurrence, and analytical methods. Compr. Rev. Food Sci. Food Saf. 2010, 9, 21-43. [CrossRef]

52. Lahimer, M.C.; Ayed, N.; Horriche, J.; Belgaie, S. Characterization of plastic packaging additives: Food contact, stability and toxicity. Arab. J. Chem. 2013, 50, 1-17.

(C) 2016 by the authors; licensee MDPI, Basel, Switzerland. This article is an open access article distributed under the terms and conditions of the Creative Commons Attribution (CC-BY) license (http:/ / creativecommons.org/licenses/by/4.0/). 